\title{
CHILD ABUSE INTERVENTION: REPORTING PROTOCOLS IN THE NEW ZEALAND HEALTH SECTOR
}

\author{
Louisa Jackson*
}

Reporting child abuse has been the subject of a long running socio-legal debate in New Zealand. Its most recent iteration is the Government's 2012 proposal to require all agencies working with children to institute protocols for referring maltreatment. However, New Zealand's health sector already operates under such a regime, with little investigation of its success. This article offers a critical analysis of the sector's protocol framework. It argues that the protocols have established a detailed and enforceable structure for referring maltreatment, but identifies inconsistencies that risk discrepancies in the treatment of vulnerable children. Accordingly, the article recommends that the framework be rationalised and suggests that the legislative proposal include universal thresholds for referral to avoid replication of this problem on a national scale.

\section{INTRODUCTION}

This year, 2013, the Government will introduce legislation requiring all agencies that work with children to have protocols governing the identification and referral of child abuse. ${ }^{1}$ This is to be in lieu of introducing a statutory mandatory reporting duty; no doubt a relief to mandatory reporting's many opponents. ${ }^{2}$ However, as it relates to the health sector, the proposal appears ill-informed. This is because a protocol-based identification and reporting regime already operates in that sector, making the change in approach somewhat artificial. Equally, consideration of how the health sector's existing regime operates seems salient when introducing a similar regime nationally. Given

* Submitted as part of the LLB (Hons) programme at Victoria University of Wellington. Recipient of the 2012 Robert Orr McGechan Memorial Prize for the Best Student Work for the Victoria University of Wellington Law Review. The author would like to thank Professor Bill Atkin for his guidance and supervision and Joss Opie for his helpful comments.

1 Ministry of Social Development The White Paper for Vulnerable Children (2012) vol I <http://www.childrensactionplan.govt.nz> at 7.

2 See for example Felicity Goodyear-Smith "Should New Zealand introduce mandatory reporting by general practitioners of suspected child abuse? NO" (2012) 4 JPHC 77. 
this, it is surprising that the White Paper announcing the proposal omits to mention the health sector's framework at all.

Accordingly, this article seeks to contribute to the proposed legislative process by exploring the comprehensiveness of the health sector's existing protocol framework. In doing so, the article analyses the nature and quality of reporting obligations contained in a cross-section of health sector protocols. Ultimately, it argues that while the protocols have established a detailed and enforceable reporting regime, problematic gaps and inconsistencies exist that risk discrepancies in the treatment of vulnerable children. Given this risk, the article concludes with two recommendations. First, that the health sector's protocol framework should be rationalised to ensure greater coherence in its application. Second, that in imposing the new duty to have reporting protocols, the Government should require specific universal standards and thresholds be included to ensure national and crosssector consistency in child abuse intervention.

\section{SCOPE AND METHODOLOGY}

\section{A The Scope of this Article}

This article aims to assess the comprehensiveness of the health sector's framework for identifying and reporting child abuse by analysing a representative sample of protocols from a range of health organisations. The article does not analyse all of the protocols individually, ${ }^{3}$ but rather focuses on the operation of the framework as a whole, with particular emphasis on the problematic variations that can be seen when the protocols are viewed comparatively. To assist the analysis, the case of "M", a severely abused girl in contact with numerous health agencies subject to the framework (but which ultimately failed to identify her abuse) is considered. ${ }^{4}$ The article excludes a range of associated issues including any reporting protocols that may operate in other professional sectors; the substantive merits (or lack thereof) of mandatory reporting obligations; any reporting obligation implicit in the recently enacted s 195A of the Crimes Act 1961; and the interaction of privacy law with disclosure of patient information in reporting processes.

\section{B Methodology for Analysis of the Protocols}

To obtain the relevant data for this study, a sample of abuse identification and reporting protocols was obtained from a cross-section of health sector organisations. Various national public sector bodies, professional associations, District Health Boards (DHBs) and public and private sector hospitals were contacted with requests for information about their child abuse referral

4 The case of M was the subject of a Ministerial Inquiry in 2011: Mel Smith Report to Hon Paula Bennett, Minister for Social Development and Employment: Following An Inquiry into the Serious Abuse of a Nine Year Old Girl and Other Matters Relating to the Welfare, Safety and Protection of Children in New Zealand (31 March 2011) [Mel Smith Report]. 
protocols. The response rate varied between public and private sector organisations, with very few private hospitals responding to the request, but a high response rate from all public agencies and professional associations. A list of all protocols obtained and reviewed is annexed as Appendix Four and a list of organisations that responded to the information request, but that did not have unique protocols, is annexed as Appendix Five.

Each protocol was individually reviewed and broken down into component parts. Three comparative tables were then produced. These are annexed as Appendix One (a comparison of the obligations and thresholds), Appendix Two (a comparison of the referral processes required) and Appendix Three (a comparison of the definitions of abuse employed). ${ }^{5}$ The tables were used to identify the consistency of the protocols across the health sector and, as such, directly inform the analysis in this article.

\section{BACKGROUND}

\section{A The Current Statutory Framework}

Despite ongoing debate about its efficacy, ${ }^{6}$ New Zealand has operated under a statutory voluntary reporting regime since the enactment of the Children, Young Persons, and Their Families Act 1989 (the Act). Section 15 of the Act permits any person who suspects a child to be at risk of abuse to report that suspicion to Child Youth and Family (CYF) or the police. However, such disclosure is not obligatory. A person who suspects abuse but does not report it is, in most situations, not acting unlawfully. ${ }^{7}$ Mandatory reporting would, by contrast, legally require disclosure (either by all persons aware of a certain level of harm, or by specified classes of persons such as health practitioners and teachers). ${ }^{8}$

However, the voluntariness of the extant reporting provision is deceptive. As an alternative to mandatory reporting, a 1994 amendment to the Act introduced a duty on the Chief Executive of the Ministry of Social Development to develop and implement protocols for reporting child abuse across a range of organisations. ${ }^{9}$ Protocols were seen as a way to establish a "coordinated and systematic" approach to reporting, including the standardisation of definitions, practices and

5 The Appendices are the work of the author and accordingly, any error is the author's.

6 See Bill Atkin "Child Abuse in New Zealand" in Michael Freeman (ed) Overcoming Child Abuse: A Window on a World Problem (Ashgate, Dartmouth, England, 2000) 305 at 307-312.

7 Subject to s 195 A of the Crimes Act 1961 which requires a limited class of persons to take "reasonable steps" to protect a child at risk of death, grievous bodily harm, or sexual assault.

8 Department of Social Welfare Report to the Minister of Social Welfare on Recommendation 2 of the Ministerial Review Team Report on the Children, Young Persons, and Their Families Act $1989-$ Mandatory Reporting (1992) at 20.

9 Children, Young Persons, and Their Families Act 1989, s 7(2)(ba)(ii). This was introduced in lieu of a mandatory reporting provision in the Act's 1994 amendment: Atkin, above n 6, at 312. 
procedures, without attracting the potentially negative consequences of a legislative reporting duty. ${ }^{10}$ Within the health sector, this resulted in the development of a complex matrix of formal abuse identification and reporting protocols that operate at multiple levels and across a variety of specialisations. ${ }^{11}$ In many situations these protocols impose enforceable obligations on health practitioners to report identified and suspected child abuse. As such, the alternative protocol framework has established a de facto mandatory reporting regime within the New Zealand health sector. ${ }^{12}$ Thus, as envisaged by earlier commentators, the 1994 protocol initiative may well have achieved "much the same impact" as a legislative duty to report. ${ }^{13}$

\section{B The Recent Mandatory Reporting Debate and the Green and White Papers}

Perhaps due to the relative anonymity of the reporting regime established by the protocol framework, mandatory reporting of child abuse has continued to be a much debated socio-legal policy in New Zealand. ${ }^{14}$ It resurfaced as the subject of considerable public attention in 2011, a consequence of its inclusion in the Government's Green Paper for Vulnerable Children and its recommendation in several prominent official inquiries into child maltreatment. ${ }^{15}$ In October 2012 the Government once again laid the debate to rest by announcing in its White Paper for Vulnerable Children (White Paper) that "rather than introduce mandatory reporting now", it will "introduce legislative change to require agencies working with children to have child protection policies in place covering the identification and reporting of child abuse and neglect". ${ }^{16}$ To guide the development of these agency policies, a national "code of practice" will also be released. ${ }^{17}$ Once the new regime is "embedded", the Government's position on mandatory reporting will again be reviewed. ${ }^{18}$ As noted earlier, the White Paper omits any mention of the existing protocol

10 Department of Social Welfare, above n 8, at 46.

11 See Appendix Six for a simplified chart of the protocol framework.

12 See Auckland District Health Board "Child Abuse, Neglect, Care and Protection Policy" (May 2011) PP01/PCR/002 at 12 (Obtained under Official Information Act 1982 Request to the Legal Team, Auckland District Health Board); and see In the Matter of Inquests Into the Deaths of Christopher Arepa Kahui and Cru Omeka Kahui, Infants Coroners Court Auckland 89/12, 2 July 2012 at [228] [Kahui Inquest].

13 Atkin, above $\mathrm{n} 6$, at 313.

14 A statutory duty requiring mandatory reporting of child abuse has been considered and rejected by successive New Zealand Governments since 1984: see Atkin, above n 6, at 307-312.

15 Ministry of Social Development Every child thrives, belongs, achieves: The Green Paper for Vulnerable Children (Public Consultation Paper, 2011) at 24; Kahui Inquest, above n 12, at [228]; Mel Smith Report, above $\mathrm{n} 4$, at [8.46].

16 Ministry of Social Development The White Paper for Vulnerable Children (2012) vol II at 81 and 165.

17 At 81

18 At 81. 
framework. This is of some concern, particularly as the proposal is essentially a national scale replication of the health sector's protocol regime. This regime is discussed below.

\section{IDENTIFYING AND REFERRING CHILD ABUSE IN THE NEW ZEALAND HEALTH SECTOR}

\section{A An Overview of the Protocol Framework}

The centrality of the health sector to an effective national child abuse intervention strategy is widely accepted. ${ }^{19}$ Almost every child engages with some health practitioner during their childhood and the extensive involvement of particularly vulnerable children with health services is well documented. ${ }^{20}$ Given this, the approach to abuse identification and referral in the protocol framework is suitably comprehensive. Such comprehensiveness can be seen in the multi-levelled nature of the framework, ensuring coverage nationally and sector-wide, and in the level of detail that individual protocols contain. However, when considered as a whole, the framework presents as a complex configuration of duties, at points operating in tension with each other, and at others, falling short of the stated intention for a standardised approach. Thus, despite the advantages of the framework in terms of detail and coverage, there is scope for improvement.

The framework's approach to abuse identification and referral is unpacked below. First, the levels of the framework are highlighted in Part A1; second, the origins of the protocols at each level are noted in Part A2; third, the framework's general approach to intervention is identified in Part A3; and lastly, its problems are considered in detail in Parts B, C and D. Part V considers the framework's enforceability and Part VI makes recommendations for reform.

\section{A "multi-levelled" approach: the layers of the protocol framework}

The health sector's reporting framework is formed by a cross-section of protocols at national, regional and local levels. First, at national level, comprehensive guideline documents are produced by executive bodies such as CYF and the Ministry of Health (MOH) ${ }^{21}$ These documents inform the

19 Office of the Commissioner for Children Executive Summary of the Report into the Death of James Whakaruru (2000) at 4; Office of the Commissioner for Children The Role of Primary Health Care Providers in Identifying and Referring Child Victims of Family Violence (2000) at vi; Janet Fanslow Beyond zero tolerance: key issues and future directions for family violence work in New Zealand (Families Commission, Research Report 3/05, August 2005) at 26.

20 James Whakaruru was seen 40 times by health practitioners before his death. See Office of the Commissioner for Children Executive Summary of the Report into the Death of James Whakaruru (2000) at 4. "M" was involved with nine separate health sector organisations before her severe abuse was identified. See Mel Smith Report, above n 4, at 29.

21 Child Youth and Family "An Interagency Guide: Working Together to Keep Children and Young People Safe" (February 2011) CYF045 (Obtained under Official Information Act 1982 Request to Child Youth and Family); Ministry of Health "Family Violence Intervention Guidelines: Child and Partner Abuse" (2002) (Obtained under Official Information Act 1982 Request to the Ministry of Health). 
development of more specific protocols, particularly those of DHBs. In addition, there are national interagency agreements on reporting processes, principally specified in a Memorandum of Understanding between CYF, the police and DHBs. ${ }^{22}$ National professional associations such as the Medical Council and the New Zealand Dental Association also specify identification and referral obligations for their members in professional guidelines and codes of practice. Second, at regional level, every DHB in New Zealand has their own abuse identification and referral protocols that apply to all DHB services such as hospitals, primary health organisations and community clinics. ${ }^{23}$ Third, at local level, individual hospitals and health sector agencies such as the Royal New Zealand Plunket Society (Plunket) ${ }^{24}$ also produce abuse reporting protocols that apply to their staff and volunteers. ${ }^{25}$ This multi-layered approach ensures coverage of practitioners working across the sector, but equally contributes to the framework's complexity.

\section{The origins of the protocols}

The protocols originate from different sources at each level. First, as noted above, the national interagency protocols are a requirement of the Act. ${ }^{26}$ However, at regional level, the DHB protocols are the result of national funding obligations contained in the Crown Funding Agreement between the MOH and DHBs. This agreement requires DHBs to develop and implement "referral policies" for identified or suspected victims of abuse, ${ }^{27}$ a recommendation of the (then) Commissioner for

22 Child Youth and Family, New Zealand Police and District Health Board "Memorandum of Understanding between Child Youth and Family, New Zealand Police and District Health Boards" (August 2011) (Obtained under Official Information Act 1982 Request to Child Youth and Family).

23 Jane Koziol-McLain, Claire Gear and Nick Garrett Hospital Responsiveness to Family Violence: 84 Month Follow-Up Evaluation (Interdisciplinary Trauma Research Centre, 2011) at 16. Note that primary health organisations (employing general practitioners and practice nurses) are also DHB organisations: Ministry of Health "About Primary Health Organisations" (23 October 2012) <www.health.govt.nz>

24 Plunket is a charitable organisation providing free parenting support and child health services in New Zealand. The organisation works principally with infants and their mothers, visiting 90 per cent of all new born children in New Zealand to assess infant health and provide education about child care. Plunket is funded by the Government, as well as through corporate sponsorship, and private donations. See Plunket "Who we are" (2013) <www.plunket.org.nz> and Plunket "Our organisation" (2013) <www.plunket.org.nz>

25 See Starship Hospital "Starship Children's Health and Clinical Guideline: Child Abuse and Neglect" (May 2010) (Obtained under Official Information Act 1982 Request to Legal Team, Auckland District Health Board); Royal New Zealand Plunket Society "Family Violence Prevention Policy and Protocols" (July 2008) (Obtained by personal request to Plunket).

26 Children, Young Persons, and Their Families Act, s 7(2)(ba)(ii).

27 Ministry of Health "Service Specification: Violence Intervention Programme" at 4 (Obtained under Official Information Act 1982 Request to Ministry of Health). 
Children following an investigation into a child's death by maltreatment in $2000 .{ }^{28}$ Locally, hospitals and other health services are required by the New Zealand Standards to protect patients from abuse or neglect, ${ }^{29}$ with referral protocols specified as a means to satisfy this obligation. ${ }^{30}$ Lastly, in contrast to the legislative or regulatory origins of the other protocols in the framework, professional associations voluntarily developed their own protocols in response to perceived social and professional need. ${ }^{31}$ In sum, the protocols that form the national framework have arisen from divergent sources, which may help to explain the discrepancies between them.

\section{Identifying and referring abuse: the general approach required by the framework}

Across all levels the protocols follow a comprehensive, and relatively consistent, approach to abuse intervention. Obligations (either voluntary or mandatory) to identify and report abuse are specified, lists of indicators and symptoms of abuse to which practitioners should be alert are provided, consultation procedures are set out, and thresholds of the requisite harm and risk to activate any reporting duty are listed. This detailed approach ensures reports are necessary and of high quality, reducing the risk of over-reporting. ${ }^{32}$ The comprehensiveness of the protocols, some of which number hundreds of pages, would be difficult to replicate in any other form, a clear advantage of a protocol approach over a bare legislative reporting duty.

\section{B Broad Issues in the Protocol Framework}

\section{Complexity and inconsistency: the regime's problems at a glance}

While the framework's comprehensive approach provides benefits in ensuring national coverage and providing the detail necessary for effective implementation, it also creates problems. First, the multi-levelled nature of the protocols creates complexity as it means that one health practitioner may be subject to multiple but inconsistent protocols. For example, a doctor employed by a DHB and practising in a hospital with a unique referral protocol would be required to comply with both organisations' protocols simultaneously. In addition, the same doctor would be subject to his or her professional association's code of conduct to ensure compliance with professional best practice standards. As there are variations in the detail of the protocols at each of these three levels, the

28 Steve Maharey "Government agencies responding to Te Riri o te Rangi James Whakaruru report" (press release, 2 February 2001).

29 Health and Disability Services (Core) Standard NZS 8134.1:2008, standard 1.3.7.

30 At 1.3 .7 .

31 Email from Hugh Trengrove (Associate Director of Research and Policy at the New Zealand Dental Association) to Louisa Jackson (author) regarding the New Zealand Dental Association's child abuse referral protocol (1 August 2012).

32 See Goodyear-Smith, above n 2, at 79. 
multiplicity of protocols may create ambiguity for health practitioners in discharging their legal obligations.

Second, the protocol framework contains a concerning level of variation. Not all organisations follow the general approach outlined at Part A3 above and some protocols contain quite different details to others. Such variation weakens the protocol framework as a cohesive sector-wide strategy to child abuse intervention. Particular areas of concern include differences in the compulsion of the reporting duty, and in the specific elements requisite to engage the duty, if it exists. These issues are examined at Parts B2 and $\mathrm{C}$ below.

\section{Incompleteness: a partial mandatory reporting regime}

The protocol framework does not uniformly compel reporting by all health practitioners. Rather, the strength of reporting obligations varies throughout the sector, particularly between public and private organisations. Importantly, every DHB protocol contains an explicit mandatory reporting duty. ${ }^{33}$ Therefore, all practitioners employed in public health services are subject to compulsory reporting. Outside the public sector, however, reporting obligations are not consistent.

Not all private sector organisations impose mandatory reporting duties on their employees. While Plunket and Southern Cross Hospital have explicit reporting duties, other private health employers do not, revealing a gap in the framework. ${ }^{34}$ For example, Wakefield Hospital encourages, but does not compel, reporting of third party abuse of child patients. The hospital specifies that employees "should" report suspicions of third party abuse, ${ }^{35}$ as compared with an explicit requirement that employees "shall" report any abuse of patients by other hospital staff. ${ }^{36}$ Thus, it is not mandatory for practitioners employed by Wakefield Health to report identified or suspected abuse that occurs outside of the hospital. This shows that different reporting obligations exist between public and private sector organisations.

The protocols of professional associations also contain variations in reporting duties. Not all professional associations have identification and referral protocols. ${ }^{37}$ Equally, some professional

33 Auckland District Health Board, above n 12, at 12; and see Appendix One for the particular wording of the reporting obligations contained in the Auckland District Health Board, Capital and Coast District Health Board, and Hutt Valley District Health Boards' protocols.

34 Royal New Zealand Plunket Society, above n 25, at 5; Southern Cross Hospitals Limited "Prevention of Patient Abuse, Neglect or Maltreatment" (February 2012) Doc 3.3 KB 4236 at 3 (Obtained by personal request to Southern Cross Hospitals National); and see Appendix One for a comparison of the reporting duties across the sector.

35 Wakefield Health Limited "Policy: Abuse and Neglect" (July 2011) WHLC.01.08 at 5 (Obtained by personal request to Wakefield Hospital).

36 At 2 .

37 See Appendix Five for a list of professional associations that do not have reporting protocols. 
associations that do have protocols do not specifically address reporting. ${ }^{38}$ Thus, practitioners within these professions, such as paediatricians, psychiatrists and nurses, will be subject only to their employer's reporting protocol (if any). In addition, most professional associations that do have protocols which address child abuse do not state expressly whether they require their members to report. ${ }^{39}$ Rather, reporting duties are implicit in the protocol's wording and would therefore be discretionary in application. For example, the Medical Council requires "referral" when in the patient's "best interests", ${ }^{40}$ the New Zealand Dental Association states its members "should" (rather than "must") report, ${ }^{41}$ and the New Zealand Association of Counsellors specifies a permissible discretion to report when abuse is suspected, but without mandating this. ${ }^{42}$ It should also be noted that some professional associations, notably the New Zealand College of Midwives, expressly oppose compulsory reporting of child abuse. ${ }^{43}$ This means that professional best practice obligations cannot fill the gap created by the inconsistent reporting duties of health sector employers, and accordingly, that the protocol framework may be incomplete.

Considered as a whole, the inconsistent approach to reporting obligations in the framework reveals the potential for standards of child protection to vary across the health sector. First, the difference in reporting duties between public and private bodies means that the same child presenting in different services will receive different standards of protection. For example, the Paediatric Society of New Zealand has no child abuse intervention protocol, ${ }^{44}$ meaning that paediatricians practising in a private hospital may be under no obligation to report identified or suspected abuse. By contrast, paediatricians employed in the public sector have a clear obligation to report. Thus, a child treated in Wellington Hospital technically receives greater protection than the same child treated in Wakefield Hospital. Equally, the New Zealand College of Midwives does not require its members to report abuse to comply with professional best practice standards. ${ }^{45}$ However,

38 See for example New Zealand Nurses Organisation "Practice Position Statement: Family Violence" (February 2009) (Obtained by personal request to the New Zealand Nurses Organisation).

39 See Appendix One for a breakdown of the reporting obligations set by professional associations.

40 Medical Council of New Zealand "Good Medical Practice: A Guide for Doctors" (June 2008) at 5 (Obtained by personal request to the Medical Council of New Zealand).

41 New Zealand Dental Association "Practice Guideline: Guidelines for Child Protection" (September 2006) at 1 (Obtained by personal request to the New Zealand Dental Association).

42 New Zealand Association of Counsellors Policy Manual: Reporting Possible Child Abuse (October 1992) at [3.24] (Obtained by personal request to the New Zealand Association of Counsellors).

43 New Zealand College of Midwives "Consensus Statement on Family Violence" (2002) (Obtained by personal request to the New Zealand College of Midwives).

44 Email from Patrick Kelly (Paediatrician, Starship Children's Hospital) to Louisa Jackson (author) regarding the Paediatric Society's child abuse referral protocol (13 February 2012).

45 New Zealand College of Midwives, above n 43, at 1. 
midwives employed by a DHB (rather than independently) would be subject to compulsory reporting duties by virtue of their employment. As such, a child will technically receive different standards of protection depending on whether its mother elects a public or private midwife.

Second, differences in reporting duties between organisations may also mean that two practitioners caring for one family will employ different approaches to intervention. This is again illustrated with pregnant women and their families, a group that engages with both midwives and Plunket nurses over the course of ante and post-natal care. Both midwives and Plunket nurses will have similar information about the family's home environment, parental competence, and the wellbeing of its children. However, Plunket nurses are subject to markedly different reporting obligations from independent midwives. Plunket nurses must report identified or suspected child abuse and Plunket, as an organisation, endorses mandatory reporting. ${ }^{46}$ By contrast, as noted above, independent midwives are not required to report abuse and their professional body opposes mandatory reporting. ${ }^{47}$ Such a discrepancy in approach between two practitioner groups engaging with the same health service users is concerning and may lead to families being subject to different standards of intervention without any clear rationale for such variation.

\section{The consequences of variations in reporting standards: the case of $M$}

The consequence of variations in reporting standards for the protection of vulnerable children is reflected in the case of M. M and her abusive mother were counselled by an Accident Compensation Corporation funded, ${ }^{48}$ but independent, counsellor. ${ }^{49}$ Not being employed by a DHB meant that the counsellor was not subject to a compulsory reporting duty by virtue of her employment. In addition, there was no professional duty to report, as neither the New Zealand Association of Counsellors, nor the New Zealand College of Clinical Psychologists, requires their members to report abuse to comply with professional competency standards. ${ }^{50}$ For M, the seemingly arbitrary fact that her counselling was organised via ACC, rather than through general DHB services, meant that disclosures of abuse made by her mother in the course of the counselling sessions were not required to be reported. The counsellor had legal discretion to choose whether to report the disclosure and elected not to. ${ }^{51}$ Eight days later, $\mathrm{M}$ was subject to a severe and prolonged period of assault and

46 Royal New Zealand Plunket Society, above n 25, at 5.

47 New Zealand College of Midwives, above n 43, at 1 .

48 The Accident Compensation Corporation is, briefly, a Crown organisation that provides financial cover for the treatment of injuries, including professional counselling for "mental injuries" that result from sexual assault or abuse. See Accident Compensation Corporation "Counselling" (20 June 2008) <www.acc.co.nz>.

49 Mel Smith Report, above n 4, at [3.15].

50 New Zealand Association of Counsellors, above n 42, at [3.24]; New Zealand College of Clinical Psychologists Code of Ethics for Psychologists Working in Aotearoa New Zealand (April 2004) at 6 (Obtained by personal request to the New Zealand College of Clinical Psychologists).

51 Mel Smith Report, above n 4, at [3.15.4]. 
maltreatment, ${ }^{52}$ resulting in her mother's conviction and imprisonment for 25 criminal charges. ${ }^{53}$ Notification to CYF may have protected $\mathrm{M}$ by ensuring earlier intervention in the increasingly volatile family situation. Given that such notification may have occurred had $\mathrm{M}$ and her mother been counselled through a DHB facility with a mandatory reporting policy, the risk of the current protocol framework leading to an "intervention lottery" is revealed. This is self-evidently inappropriate: the level of protection provided to our most vulnerable children should not differ depending on such a random factor as who happens to be the treatment provider.

\section{Specific Issues in the Protocol Framework: Variations in the Elements that Activate the Reporting Duty}

In addition to specifying general duties to report, the framework also stipulates certain elements that, when present, will activate the duty. As with variations in the strength of the reporting duties themselves, the framework also contains variations in the elements that engage the duty. Such variations include: the particular behaviours or omissions that are prescribed as constituting abuse, the coverage of unborn children, the inclusion of a risk of future harm rather than solely existing or past harm, the degree of harm or risk that must be present to report, and the state of knowledge or awareness required of the reporter. These five elements are explored below.

\section{A fundamental question: what constitutes abuse?}

The definition of abuse goes to the heart of any reporting regime. Definitions of abuse set the parameters of what is considered acceptable treatment of children and accordingly, they specify the types of behaviour that will, and will not, require referral. ${ }^{54}$ As such, the definition employed sets a critical threshold for any abuse intervention protocol. If a definition is too broad it will result in "unnecessary and counterproductive" over-reporting of minor issues. ${ }^{55}$ However, narrow definitions may exclude more subtle but equally harmful forms of violence, such as psychological or emotional abuse. Given this tension, and the importance of ensuring nationally consistent treatment of vulnerable children, uniformity in the definition of abuse is essential. Indeed, this was noted as one of the purposes behind the development of protocols when the initiative was first introduced. ${ }^{56}$ However, beyond a general reflection of the four-fold statutory definition of abuse (encompassing

52 Mel Smith Report, above n 4, at [2.60].

53 Edward Gay and Amelia Romanos "Bennett: Mother Failed Her Child" New Zealand Herald (online ed, New Zealand, 21 December 2011).

54 Ben Mathews and Maureen C Kenny "Mandatory Reporting Legislation in the United States, Canada and Australia: A Cross-Jurisdictional Review of Key Features, Differences and Issues" (2008) 13 Child Maltreat 50 at 52.

55 Goodyear-Smith, above n 2, at 79.

56 Department of Social Welfare, above n 8, at 46 
physical, sexual and emotional abuse and neglect), notable variations exist as to what is sufficient to warrant referral.

First, the definitions of abuse between the MOH and CYF national guideline documents vary. ${ }^{57}$ The inconsistency is seen particularly in the definition of emotional abuse. The MOH uses a markedly wider definition than CYF. For example, in addition to the types of behaviour that constitute emotional abuse specified by CYF, the MOH includes: ${ }^{58}$

... inappropriate expectations of the child, exposure to family violence, corruption of the child through exposure to or involvement in illegal or antisocial activities, the negative impact of the mental or emotional condition of the parent, the negative impact of substance abuse by anyone living in the same residence as the child.

Thus, a wide range of social issues such as adult mental illness or participation in criminal offending is swept into the MOH definition of child abuse. Whether this broad definition is appropriate from a normative perspective is outside the scope of this article. However, as different DHBs adopt different national guideline documents as a template for their protocols, the discrepancies in definition create a chain of inconsistencies across the national framework. While the Hutt Valley District Health Board (HVDHB) and the Capital and Coast District Health Board (CCDHB) employ the $\mathrm{MOH}$ definition for all four categories of abuse, the Auckland District Health Board (ADHB) does not. Rather, the ADHB protocol omits detailed definitions of any category of abuse but instead references the CYF interagency guide. ${ }^{59}$ Thus, technically, an adult presenting as a patient to an ADHB clinician with substance abuse or mental health issues would not activate a reporting duty in respect of any children living in their home, while the same adult presenting in a HVDHB or CCDHB service would automatically engage a referral obligation.

Problematic variations in definition can also be identified between individual hospital protocols. While each protocol can generally be interpreted as covering the four categories of abuse in the statutory definition, the detailed definitions specified by each were mutually inconsistent. ${ }^{60}$ For example, Southern Cross does not specify what constitutes emotional abuse beyond an (unusual) reference to the "wilful infliction of ... debilitating mental anguish". ${ }^{61}$ Such a definition sets a very high threshold to engage a reporting duty, requiring the perpetrator to commit the abuse intentionally (indicated by the word "wilful") and for the resultant harm to the child to be serious (indicated by the word "debilitating"). This narrow definition is quite inconsistent with the notably

57 See Appendix Three for the specific wording of each agency's definition

58 Ministry of Health, above n 21, at 84 .

59 Auckland District Health Board, above n 12, at 4.

60 See Appendix Three for a breakdown of the definitions used in each protocol.

61 Southern Cross Hospitals, above n 34, at 1. 
wide range of behaviours identified as constituting emotional abuse within the public health sector. In theory, it would mean that a child presenting at a Southern Cross hospital with signs of emotional abuse as a consequence of, say, witnessing violence between his or her parents would not meet the standard to activate a referral. However, the same child presenting at a DHB hospital would engage the duty.

Lastly, there is a distinct absence of definitions in most professional associations' protocols. Such an omission is problematic, as without identifying what constitutes appropriate and inappropriate behaviour, members of professional associations are left without clear guidance on when their professional standards necessitate intervention. Two professional associations did provide definitions of abuse. However, these specified notably higher thresholds than the national guideline documents. The New Zealand Dental Association, while employing the statutory definition of abuse, specified that for emotional harm or neglect to amount to abuse and therefore engage the (discretionary) reporting duty, it must be "serious". ${ }^{62}$ Likewise, the definition employed by the Australasian College of Emergency Medicine specified that harm to a child is not abuse unless it is "significant". ${ }^{63}$ As such, children engaging with practitioners outside the DHB environment, for example at a private dental practice, would need to exhibit greater levels of harm to attract the same standard of intervention.

\section{The subjects of the protective duty: does the framework extend to unborn children?}

While the protocol framework is consistent in its coverage of children and young people aged from birth to 17 years, a notable discrepancy exists in respect of unborn children. ${ }^{64}$ This is particularly evident at DHB level, as the protocols employed at all other levels of the framework do not identify whether they include unborn children at all. However, between the DHBs two inconsistencies can be identified: the threshold definition of "child"; and the principles of intervention to be applied once the risk of abuse is identified.

First, the definition of "child" varies between DHBs. ADHB specifically includes "the unborn child" in its definition of "child", 65 while HVDHB and CCDHB do not, specifying instead that a

62 New Zealand Dental Association, above n 41, at 2.

63 Australasian College of Emergency Medicine "Policy on Child at Risk" (2005) P35 at [1.2.1] (Obtained by personal request to the Australasian College of Emergency Medicine).

64 This also raises an interesting difference between New Zealand and comparable jurisdictions such as Australia and the United States where pre-natal abuse is generally not included in compulsory reporting duties: Mathews and Kenny, above n 54, at 57. As such, the protocol framework may represent a more efficacious referral regime than the legislative reporting duties that exist in those jurisdictions.

65 Auckland District Health Board, above n 12, at 4. 
"child" is aged from $0-14 .{ }^{66}$ However, while CCDHB does not include an unborn child in its threshold definition, its protocol unequivocally applies to such children. The reporting duty specified in the protocol specifically notes that it "includes at risk unborn babies". ${ }^{67}$ Accordingly, both ADHB and CCDHB staff members are compelled to report identified, suspected or potential foetal abuse or harm, while HVDHB staff are not.

Such discrepancy raises the potential for national variations in the standard of protection provided to foetuses and the level of intervention to which pregnant women are subject. ${ }^{68}$ For example, a pregnant woman presenting at a DHB facility in the Hutt Valley region would not, according to the protocol, be subject to screening for foetal abuse or neglect, or ultimately, to the potential for referral to child protection agencies. However, the same woman presenting at a DHB facility in the Auckland or Wellington regions would fall under the protocol's ambit and potentially be subject to referral. Such variation in the approach to foetal protection between public health bodies is contrary to the framework's intention for a nationally consistent approach to child protection.

Second, the two DHB protocols that do clearly apply to unborn children contain variations in both the principle and substance of referral. First, the ADHB protocol expressly states that "assessment and management of risk to pregnant women and the unborn child" are subject to the principle of maternal autonomy. ${ }^{69}$ The mother is acknowledged as "wholly responsible" for consent to medical procedures during pregnancy "even where this impacts on the unborn child" and the impact of referral on "the appropriate care of pregnant women" is a relevant consideration in any foetal protection process. ${ }^{70}$ Accordingly, the ADHB protocol implies that referrals relating to unborn children must follow a balancing exercise between the mother's interests and those of her

66 Hutt Valley District Health Board "Child Abuse and Neglect Policy" (December 2011) VIP.001 at 10 (Obtained under Official Information Act 1982 Request to the Legal Team, Hutt Valley District Health Board); Capital and Coast District Health Board "Family Violence Intervention Policy, Procedures and Protocols" (9 August 2010) ID 1.1154 at 51 (Obtained under Official Information Act 1982 Request to the Legal Team, Capital and Coast District Health Board).

67 Capital and Coast District Health Board, above n 66, at 13.

68 The protective jurisdiction of the Children, Young Persons, and Their Families Act applies to unborn children: Re Baby P (an unborn child) [1995] NZFLR 577 (FC); Re An Unborn Child [2003] 1 NZLR 115 (HC). This means that referring a risk of foetal harm may result in a court compelling a pregnant woman to act in accordance with the "best interests" of her foetus, even where this impedes her autonomy: see Re An Unborn Child [2003] 1 NZLR 115 (HC).

69 Auckland District Health Board, above n 12, at 3.

70 Auckland District Health Board, above n 12, at 3. 
foetus. Only where the risk to a foetus is sufficiently serious to outweigh the mother's recognised right to make decisions in respect of her body ${ }^{71}$ would referral be required.

In contrast, the CCDHB protocol is significantly more robust in its application to unborn children. Rather than making the duty to report conditional on maternal interests, it is unequivocally engaged whenever there is "imminent harm" to the life of a foetus or where "significant risk factors" exist that indicate a foetus is at risk in utero, or will be at risk at the time of birth. ${ }^{72}$ Unique risk factors are listed in the protocol, including maternal unwillingness to receive medical or antenatal care and maternal mental health or substance abuse issues. ${ }^{73}$ However, these factors all involve direct conflicts with maternal autonomy which is not specified as a relevant consideration in the protocol. For example, a pregnant woman who provides an advance directive refusing blood transfusions due to her religious beliefs would put the life of her foetus at risk and accordingly, activate a reporting duty. Similarly, a pregnant woman presenting to a community mental health clinic with depression, or who disclosed alcohol abuse to her doctor, would be automatically subject to referral to CYF for foetal protection.

\section{Prevention or cure: is the reporting duty engaged in respect of future harm?}

The protocol framework is, largely, both preventive and curative in intent. Reporting duties are engaged by identification of existing or historic abuse or by suspicions of a risk of future harm. ${ }^{74}$ This is particularly evident in DHB protocols where the existence of "risk factors" such as a child being mentally impaired, perceived as "naughty", or whose parents have mental health issues, criminal affiliations or a history of family violence, will automatically activate a reporting duty, even without the child exhibiting physical or behavioural signs of abuse. ${ }^{75}$ Equally, the majority of individual health employers' and professional associations' protocols can be interpreted as applying to future harm. For example, employers such as Plunket specify that the reporting duty is engaged where a "risk" of abuse exists, ${ }^{76}$ as do professional associations such as the New Zealand Association of Counsellors. ${ }^{77}$

71 See Right to Life New Zealand Inc v Abortion Supervisory Committee [2008] 2 NZLR 825 (HC) at [77] and [78]; Wall v Livingston and Roborgh [1982] 1 NZLR 734 (CA) at 740.

72 Capital and Coast District Health Board, above n 66, at 22.

73 Capital and Coast District Health Board, above n 66, at 22-23.

74 See Appendix One at "Threshold of Harm Required" for a detailed breakdown.

75 Capital and Coast District Health Board, above n 66, at 55; Hutt Valley District Health Board, above n 66, at 13 .

76 Royal New Zealand Plunket Society, above n 25, at 17.

77 New Zealand Association of Counsellors, above n 42, at [3.24]. 
However, in contrast to the general preventive approach adopted in the framework, private hospitals exclude future harm from their reporting duties. Neither Wakefield nor Southern Cross Hospitals specify "risk" as a level of harm sufficient to engage a duty to report, whether obligatory or voluntary. In addition, the definitions of abuse employed by the hospitals are framed in the past or present tense such as "harmful ... effects caused by another person", ${ }^{78}$ or the "infliction of ... pain", ${ }^{79}$ technically restricting the duty to situations of existing or past harm alone.

\section{The problem of identification}

Identification of abuse is, arguably, the most critical element of any reporting framework. Unidentified abuse will not be notified regardless of how robust a reporting duty is. However, as detection of abuse is inherently complex, identification may also be the framework's most difficult component. ${ }^{80}$ Given this, a well-considered and consistent approach to identification is essential to the efficacy of the protocol framework as a national strategy, as this will assist in ensuring consistency in the types of cases reported and, ultimately, investigated. Despite this, the identification processes contained in the protocol framework vary significantly at each level. ${ }^{81}$ This can be seen between national agencies and DHBs, between the DHBs themselves, between individual hospitals, and also between professional associations.

First, the DHBs analysed in this study do not uniformly follow the MOH guideline for child abuse identification. The $\mathrm{MOH}$ national guideline recommends identification through questioning and physical examination of children who present with "signs and symptoms" of abuse or who fit within an identified "high risk" group. ${ }^{82}$ Numerous and wide-ranging indicators are specified to alert practitioners to the need for further examination. ${ }^{83}$ Presumably this approach is based on a principle that providing a specified list of indicators available for regular reference during practice is the most effective means of consistently identifying abuse in child patients.

The CCDHB and HVDHB protocols mirror this general approach by utilising indicia of child abuse that, if present, require abuse to be included in a differential diagnosis. ${ }^{84}$ However, the CCDHB employs its own unique indicators, rather than using those of the MOH. In particular, the CCDHB specifies risk factors such as the parent's "failure to visit" the child, "poor bonding"

78 Wakefield Health Limited, above n 35, at 1 (emphasis added).

79 Southern Cross Hospitals, above n 34, at 1 (emphasis added).

80 Fanslow, above n 19, at 27.

81 For a specific comparison of the identification processes contained in each protocol see Appendix Two.

82 Ministry of Health, above n 21, at 27.

83 Ministry of Health, above n 21, at 55-56.

84 Capital and Coast District Health Board, above n 66, at 16; Hutt Valley District Health Board, above n 66, at 5 . 
between the parent and child, the parent having "multiple or transient partners", or an "unstable home or lifestyle". ${ }^{85}$ In addition, the CCDHB omits both the "physical" and "behavioural" signs and symptoms that the $\mathrm{MOH}$ guideline specifies. This means that, unusually, the CCDHB does not include objective and high specificity indicators in its identification procedure such as the child displaying "aggression" or "anxiety", or presenting with "developmental delay", "poor hygiene" or "sexually transmitted diseases", ${ }^{86}$ while at the same time including subjective and value-laden factors such as the nature of the parent's private sexual relationships as indicative of maltreatment. Such an approach risks over-identification, potentially subjecting a wide range of families to intrusive child protection processes. Ultimately, it may also lead to significant inconsistencies between DHBs in the types of cases identified (and thus reported) as suspicious.

The ADHB also diverges from the $\mathrm{MOH}$ guideline by adopting a unique approach to identification. Rather than specifying predetermined indicia of abuse or neglect, the ADHB requires staff to be "aware of signs of abuse" and "risk factors" when engaging with children. ${ }^{87}$ Such indicators are specified as "covered in training", 88 and not included in the protocol. This approach may allow much greater detail of identification processes to be conveyed to staff, and also reduces the risk of the protocol becoming over-prescriptive. However, by excluding indicia of abuse and neglect, it may also reduce the enforceability of the protocol as a legal standard of care. If indicators of abuse are not specified, the scope for clinicians to make discretionary or subjective decisions about what behaviour should, and should not be, identified as problematic and ultimately reported, is much wider. Therefore, this approach risks undermining the principle of mandatory reporting that the $\mathrm{MOH}$ has required the health sector to adopt: that is, the minimisation of discretion in referral decisions through imposing consistent duties to report whenever certain, objective, factors are present. ${ }^{89}$

Second, discrepancies in identification procedures are also evident at the level of individual hospitals. One private hospital protocol contained no specified guidance for identifying child abuse at all. ${ }^{90}$ This manifestly weaker approach to setting identification processes raises the possibility that a child presenting to a private hospital, such as Wakefield, may receive a lower standard of protection from abuse than the same child presenting to a DHB hospital. This again indicates that the framework's inconsistencies may lead to an intervention lottery for children.

85 Capital and Coast District Health Board, above n 66, at 55-56.

86 Per Ministry of Health Guideline, above n 21, at 56.

87 Auckland District Health Board, above n 12, at 8.

88 Auckland District Health Board, above n 12, at 8

89 Department of Social Welfare, above $\mathrm{n} 8$, at 20 .

90 Wakefield Health Limited, above $\mathrm{n} 35$. 
The remaining two hospitals in this study followed the general approach to identification modelled by the $\mathrm{MOH}$ through providing indicia of abuse to alert their staff to the need for further enquiry. However, these hospitals used different indicators to each other and to the DHBs. Notably, at Starship Hospital, abuse is required to be included in a differential diagnosis whenever a child presents with certain physical or behavioural symptoms or where the medical history is inconsistent with the injury or age of the child. ${ }^{91}$ However, the specific indicators provided are unique to the hospital and not reflected in its parent ADHB protocol (which does not employ abuse indicia at all). Such variation between the protocols of one regional public health body is problematic: for example, it may lead to ambiguities for practitioners attempting to implement their employer's internally inconsistent protocols.

Finally, professional associations' protocols are also inconsistent in their approach to the identification of abuse or neglect. Some do not provide any relevant indicators, instead simply requiring "screening" to be undertaken, ${ }^{92}$ or, more ambiguously, that the patient's condition be "adequately assessed".93 Other protocols provide no guidance on abuse identification at all, ${ }^{94}$ or set the requirement to identify abuse so widely that the practitioner is required to consider child abuse as a differential diagnosis when a child presents with any injury, failure to thrive or behavioural problem. ${ }^{95}$ Such inconsistency in the approach to, and indicators of, abuse raises the potential for discrepancies in identification between different health professions. Equally, the variations in professional associations' protocols compound the identification issues that exist between hospitals or DHBs. Where a child engages with a hospital or DHB without a comprehensive or robust identification process, professional best practice standards will not "fill the gap" to ensure the protocol framework captures all vulnerable children regardless of discrepancies at other levels.

\section{The real cost of failing to identify abuse: the case of $M$}

The harmful consequences of deficient identification procedures in the protocol framework are starkly illustrated in the case of M. The official inquiry into the case, while highlighting the failures of numerous agencies to identify or intervene in her abuse, found no direct fault of the hospitals or DHB involved. ${ }^{96}$ However, when considering the fact pattern in the official inquiry's report against the identification procedures in the protocols, a legitimate question is raised about the robustness of

91 Starship Hospital, above n 25, at 4-5.

92 New Zealand College of Midwives Midwives Handbook for Practice (2008) at 30 (Obtained by personal request to the New Zealand College of Midwives).

93 Medical Council of New Zealand, above n 40, at 5.

94 New Zealand Association of Counsellors, above n 42; New Zealand Dental Association, above n 41.

95 Australasian College for Emergency Medicine, above n 63, at [2.2].

Mel Smith Report, above n 4, at [3.6]. 
the current regime. Over an eight day period in 2010, M was under the care of three DHB providers, all of which are required to implement comprehensive identification and referral protocols. Despite this, none of the clinicians involved in her care identified either the existing abuse, or the risk of future abuse, to which $\mathrm{M}$ was subject.

The fact pattern is as follows. On 8 September, $M$ was seen by a public health nurse with an infected foot. ${ }^{97}$ She was admitted to Waitakere Hospital for treatment ${ }^{98}$ where the injury was not considered suspicious. ${ }^{99}$ Four days later, M was transferred to Starship Hospital where she was operated on, before being discharged on 15 September. ${ }^{100}$ Despite M being in 24 hour hospital care throughout this period, at no point did any clinician recognise the signs or indicators of abuse present. This may simply affirm the particular complexity and difficulty that exists in detecting abuse. On the other hand, it may reveal that the current identification process is inadequate, as the fact pattern also identifies that less than one week before admission, $\mathrm{M}$ was subject to an assault in which she was stabbed in the cheek with a fork, causing swelling sufficient to alert the concern of her teachers. ${ }^{101}$ Accordingly, there may well have been some physical indicators present that would satisfy the "signs and symptoms" of abuse specified in the MOH guideline. ${ }^{102}$

In addition, during the weeks prior to admission, $\mathrm{M}$ was reportedly displaying troubled behaviour indicative of abuse. This involved particularly aggressive acts, such as lighting fires and deliberately contaminating her infant sibling's feeding bottle with dishwashing liquid. ${ }^{103}$ Aggression, anxiety and defiance in children are all listed as behavioural indicators of abuse in the MOH guideline. ${ }^{104}$ While it is not certain that $\mathrm{M}$ continued to exhibit this type of behaviour during her engagement with DHB services, she was a seriously emotionally troubled child with an extreme pattern of behaviour. Accordingly, it is surprising that no Auckland or Waitakere DHB clinician was alerted to the potential for abuse or neglect during her eight day admission in both facilities. The failure of professionals to identify M's abuse and the risk she was subject to resulted in her experiencing continued abuse. Two months following M's engagement with the DHB services, she was severely abused over a five day period, before being found by police "starving, dehydrated and

97 Mel Smith Report, above n 4, at [2.50].

98 Waitakere Hospital is a part of the Waitemata District Health Board. However, due to constraints on scope the Waitemata DHB's protocol was not reviewed for this article.

99 Mel Smith Report, above n 4, at [2.50].

$100 \mathrm{Mel}$ Smith Report, above n 4, at [2.50].

$101 \mathrm{Mel}$ Smith Report, above n 4, at [2.49].

102 Ministry of Health, above n 21, at 56. The symptoms M reportedly exhibited may also have fallen within the indicia of abuse listed in Starship's protocol: Starship Hospital, above n 25, at 5.

103 Mel Smith Report, above n 4, at [2.47]-[2.48].

104 Ministry of Health, above n 21, at 56. 
covered in countless injuries". ${ }^{105}$ Sadly, the technical possibility exists that M's abuse and neglect may have been identified had she been admitted to a different DHB with a more comprehensive or prescriptive approach to identification.

\section{The severity of harm or risk required to activate the reporting duty}

Harm thresholds specify the severity of maltreatment that must exist before a reporting duty is engaged. This is important to ensure that "isolated or trivial incidents of less than ideal parenting" do not become the subject of state intervention. ${ }^{106}$ Harm thresholds in reporting regimes are characterised as either high or low: high threshold models require referral only where harm to a child is "serious" or "severe". ${ }^{107}$ By contrast, low threshold models compel reporting at any level of harm. ${ }^{108}$ The protocol framework employs both models, differing within protocols and also between the DHBs and private bodies. Such variation undermines a consistent approach to referral and also raises the potential that the framework may be inconsistent with child protection legislation.

First, at DHB level, the framework generally reflects a low threshold model. However, this changes dependent on to whom the report is to be made, and also between DHBs. Two of the three DHB protocols reviewed employ a high threshold model in relation to reports to the Police. The abuse or risk of abuse must be "severe" or "immediate" or a child's home environment must be "unsafe". ${ }^{109}$ Accordingly, reports to the Police are limited to the most serious cases. Conversely, reports to CYF are required at a low threshold, whenever a child has "suspicious" injuries, injuries that are "the result of abuse" or where there is "aggressive" interaction between parent and child. ${ }^{110}$ By contrast, ADHB does not specify any harm threshold necessary to activate a reporting duty. Rather, the DHB employs a "process" model, emphasising both the application of skills developed in training, and robust internal consultation, to determine whether the duty to refer is engaged in any given case. The merit of such an approach is beyond the scope of this article to consider. However, it represents a significant deviation from the threshold model specified in the MOH guideline document, and to that employed by other DHBs.

Within the private sector, there are also significant variations in reporting thresholds. The two hospital protocols reviewed did not specify any level of harm requisite to engage reporting. However, they also did not employ a process approach, such as that of the ADHB. Accordingly, their protocols could be interpreted as low threshold models, but without any specification for harm

105 Gay and Romanos, above n 53.

106 Mathews and Kenny, above n 54, at 59.

107 Department of Social Welfare, above n 8, at 19.

108 Department of Social Welfare, above n 8, at 20.

109 Hutt Valley District Health Board, above n 66, at 7.

110 Hutt Valley District Health Board, above n 66, at 4. 
set. Thus, any level of harm could require referral. This may lead to ambiguity for clinicians implementing the protocol. Such variation is also seen in professional associations' protocols. Like private hospitals, many associations do not specify any harm threshold for referral. ${ }^{111}$ However, others employ a high threshold model. For example, the New Zealand Association of Counsellors requires a "clear and imminent danger" to exist before the duty is activated. ${ }^{12}$ Similarly, the Australasian College of Emergency Medicine requires the harm or risk of harm to be "significant". ${ }^{113}$ As such, the levels of harm warranting intervention differ across the private sector.

Logically, the severity of harm warranting referral to state authorities should correspond to that required to engage the state's protective jurisdiction over vulnerable children. However, some elements of the protocol framework's harm thresholds are inconsistent with the statutory jurisdiction to intervene. Section 14(1) of the Act prescribes the level of harm required for a judicial declaration that a child is in need of care and protection. Once such a declaration is made, the care and protection procedures specified in pt 2 of the Act are permitted. Interestingly, s 14(1) employs a two-tiered model dependent on the type of abuse the child is subject to. Physical, emotional or sexual harm may exist at any level to warrant intervention and can therefore be seen as based on a low-threshold model. ${ }^{114}$ In contrast, neglect or deprivation must be "serious". 115

The protocol framework may be inconsistent with the legislative scheme to the extent that the thresholds deviate from this standard. This is particularly evident with the high threshold model employed in some professional associations' protocols that sets the bar at a notably higher level than the legislation. For example, the New Zealand Dental Association and the Australasian College of Emergency Medicine require emotional abuse to be "serious" or "significant" to engage referral, whereas this is not required in the legislation. ${ }^{116}$ Equally, an inconsistency between the legislation and the protocol framework may arise with the (presumed) low threshold model of private hospitals and the ADHB in relation to neglect. The low threshold in these protocols may sweep a wider range of harms into the referral duties than is covered by the state's jurisdiction to intervene.

\section{The level of awareness required to engage the reporting duty}

The reporter's state of awareness is another important threshold for the operation of a mandatory reporting regime. The protocol framework employs a low threshold model in terms of the level of

111 See for example, Medical Council of New Zealand, above n 40

112 New Zealand Association of Counsellors, above n 42, at [3.24].

113 Australasian College for Emergency Medicine, above n 63, at [1.2.1].

114 Children, Young Persons, and Their Families Act, s 14(1)(a).

115 Section 14(1)(a) and (b).

116 New Zealand Dental Association, above n 41, at 2; Australasian College for Emergency Medicine, above n 63, at [1.2.1]. 
knowledge or awareness required of clinicians to engage their reporting obligations. Every protocol reviewed which imposed a reporting duty, with one exception, specified "suspicion" as sufficient to warrant referral. ${ }^{117}$ By contrast, a high threshold reporting regime will require a reporter to have "knowledge" or "reasonable grounds to believe" that the subject child is being harmed or at risk thereof. ${ }^{118}$ Accordingly, the protocol framework does not require a high degree of proof to support the allegation of maltreatment in order to report. Reports may be made on a purely subjective basis wherever the reporter is alerted to the possibility of maltreatment.

\section{Discharging the Duty: Processes Required in the Protocol Framework}

Once engaged, the requirements to discharge a duty to report are broadly consistent across the framework and do not raise concern. Briefly, once a practitioner has identified abuse (or the risk thereof), consultation with colleagues or specialists about the diagnosis is required in all the reviewed protocols, with the exception of Southern Cross. ${ }^{119}$ Most organisations also require a risk assessment to be undertaken in which the particular level of risk posed to the child is determined. Documentation of evidence is required by all organisations that compel reporting, although specifications of exactly what is to be recorded vary, with some requiring photographic evidence and body maps drawn, ${ }^{120}$ and others simply requiring the practitioner to complete an "incident form". ${ }^{121}$ Following identification, consultation, risk assessment and documentation, the referral is made, either to the police or to CYF depending on the severity of harm or risk identified.

\section{THE ENFORCEABILITY OF THE CURRENT REPORTING REGIME}

The preceding parts of this article have shown that, while in need of rationalisation, an intensive reporting regime already operates in the New Zealand health sector. This part argues that the regime is also legally enforceable against practitioners in three ways: first, through the Health and Disability Commissioner (HDC); second, through the Health Practitioners Disciplinary Tribunal (HPDT); and third, through employment law. The legal enforceability of the protocol framework, together with the onerous sanctions that exist for non-compliance, further affirm the need for its greater coherence and consistency.

117 The exception to the framework's low threshold model is the New Zealand Association of Counsellors. It specifies that members must have "reasonable grounds" to suspect that a child is at risk of abuse before a professional obligation to report exists: New Zealand Association of Counsellors, above $\mathrm{n}$ 42, at [3.24].

118 Department of Social Welfare, above n 8, at 19.

119 See Appendix Two "Consultation Required?"

120 Starship Hospital, above n 25, at 7 and 9.

121 Wakefield Health Limited, above n 35, at 3. 
First, both professional protocols and the national guideline documents are enforceable through the Code of Health and Disability Services Consumers' Rights (the Code). Right 4(2) of the Code imposes a duty on health practitioners to practice in compliance with "legal, professional, ethical and other relevant standards". ${ }^{122}$ Accordingly, best practice guidelines (such as the protocols) may have equivalent status to statutory duties under this regulatory provision. ${ }^{123}$ Where a practitioner fails to meet the standards specified in these documents, a complaint may be lodged with the HDC who can investigate it as a breach of rights. If the breach is substantiated, the HDC can refer the practitioner to the Director of Proceedings who may initiate disciplinary procedures. ${ }^{124}$

This process has been used to enforce health sector protocols at least once before. A general practitioner who diagnosed and treated a seven year old girl with vaginal gonorrhoea, but who failed to report it as a likely case of sexual abuse, was found to have acted inconsistently with "interagency protocols" and "professional standards". ${ }^{125}$ Thus, the HDC declared that the practitioner acted in breach of Right 4(2) and was referred to the Director of Proceedings. The Director elected not to issue disciplinary proceedings in this instance. ${ }^{126}$

Professional protocols and best practice guidelines may also be enforced via the HPDT. The HPDT adjudicates malpractice complaints laid against practitioners. ${ }^{127}$ In determining whether a charge of professional misconduct is satisfied, the Tribunal can measure the relevant professional's conduct against the "standard of care" shown in professional protocols. ${ }^{128}$ Thus, where a practitioner fails to follow a professional obligation to refer identified or suspected abuse or neglect, they may be at risk of professional sanction. The consequences of a finding of professional misconduct by the HPDT include cancellation or suspension of the practitioner's registration or the

122 Health and Disability Commissioner (Code of Health and Disability Services Consumers' Rights) Regulations 1996, Right 4(2).

123 Ron Paterson and PDG Skegg "The Code of Patients' Rights" in PDG Skegg and Ron Paterson (eds) Medical Law in New Zealand (Brookers, Wellington, 2006) 24 at 38.

124 Health and Disability Commissioner "Complaints Resolution Overview" (2009) <www.hdc.org.nz/ complaints>.

125 Health and Disability Commissioner's Decision 01HDC01802 (30 April 2002) (Obtained under Official Information Act 1982 Request to the Health and Disability Commissioner's Office). The practitioner in this case was found to have acted in breach of child abuse management protocols predating those used in this study. However, the application of Right 4(2) would not differ if applied to contemporary protocols.

126 A request for information from the Director of Proceedings as to the reasons for this decision was declined pursuant to s 9(2)(a) and (h) of the Official Information Act 1982: Letter from Aaron Martin (Director of Proceedings) to Louisa Jackson (author) regarding a request for information on the Director's decision not to take proceedings in respect of decision number 01HDC01802 (10 August 2012).

127 Health Practitioners Competence Assurance Act 2003, s 91.

128 See In the Matter of Disciplinary Proceedings Against Christine Hawea Health Practitioners Disciplinary Tribunal Rotorua 311/Mid09/125P, 22 June 2010. 
imposition of fines up to $\$ 30,000 .{ }^{129}$ As such, non-compliance with the protocol framework may result in considerable penalties.

Lastly, but importantly, the protocols of health employers such as DHBs, individual hospitals or Plunket are also enforceable through employment law. Where a practitioner's employment agreement requires compliance with the organisation's relevant policies, failure to uphold the obligations contained in these documents can warrant dismissal on the grounds of serious misconduct, or other disciplinary action. ${ }^{130}$ Thus, compliance with the protocols may be a legal requirement of practitioners' employment, as well as of professional practice.

Accordingly, the protocol framework is currently legally enforceable. However, the inconsistencies discussed in Part IV may undermine this, and equally may mean that enforcement in its current form is inappropriate. For example, a practitioner subject to disciplinary proceedings for failing to comply with professional protocols in the HPDT may have a legitimate defence that the duties contained therein were ambiguous. ${ }^{131}$ This would particularly arise where the practitioner was simultaneously subject to multiple referral protocols (such as a DHB protocol, hospital protocol, and a professional code). In such a situation, the strength of a prosecution for professional malpractice would be impeded by the incoherence of the system itself. On the other hand, the framework's current inconsistencies mean that a practitioner working in good faith may be genuinely prevented from discharging their multiple legal duties of care; a consequence of those duties being mutually inconsistent and incoherent. This suggests that it may be inappropriate to subject practitioners to any disciplinary process for non-compliance with the current reporting regime.

\section{RECOMMENDATIONS FOR REFORM}

Parts IV and V of this article argued that the health sector's protocol framework must be rationalised for three reasons. ${ }^{132}$ First, the inconsistencies risk unjustified variations in the standard of protection offered to vulnerable children. Second, the inconsistencies undermine the policy that the protocols are intended to implement, namely the minimisation of discretion in referral

129 Health Practitioners Competence Assurance Act, s 101.

130 See Chief Executive of the Department of IRD v Buchanan and Symes CA2/05, 21 November 2005.

131 The HPDT also considers "usual professional practice" to determine the standard of care expected of a practitioner. Thus, where the protocols are ambiguous, other competent practitioners may not follow them, reducing their enforceability. See Joanna Manning "Professional Discipline of Health Practitioners" in Skegg and Paterson, above n 123, 613 at 618.

132 It is acknowledged that frequent reform of the child protection system is counterproductive and destabilising: James Mansell and others "Reframing Child Protection: A response to a constant crisis of confidence in child protection" (2011) 33 CYSR 2076 at 2077 and 2078. However, to the extent that amending the protocol framework represents an improvement to the status quo, rather than wholesale reform, these risks may be mitigated. 
decisions. ${ }^{133}$ Third, the inconsistencies create ambiguities in the legal duties of care that apply to health practitioners, reducing the legal enforceability of those duties and the practical ability of practitioners to comply with them. On that basis, this part of the article makes two recommendations for reform. First, that the health sector's framework be rationalised through a compulsory New Zealand Standard specifying a uniform approach to referring abuse across the sector. Second, that in developing its guideline code of practice, the Government specifies certain universal standards to be included in all individual agency protocols to avoid the problems identified in the health sector's framework being replicated on a larger scale.

\section{A Rationalisation of the Health Sector's Protocol Framework}

Rationalisation of the health sector's framework through a New Zealand Standard is advantageous for two reasons. First, the Standards system can easily accommodate the detailed nature of the existing protocol framework while operating at a national level and applying to a range of health organisations. Standards are set by the Standards Council, a statutory authority that creates comprehensive and enforceable regulatory documents specifying minimum standards for a range of technical industries. ${ }^{134}$ Standards are designed to reduce "confusion and inconsistencies" for practitioners implementing detailed policy and are therefore well suited to the necessary complexity of a national child abuse reporting regime. ${ }^{135}$ Second, the health sector is familiar with the Standards system as a means of national regulation. Standards are already well utilised in the sector, with all health service providers required to comply with various Standards by legislation. ${ }^{136}$ Accordingly, the creation of a new Standard to set a consistent approach to reporting would not be disruptive to service management or require legislative change. ${ }^{137}$

The obvious difficulty with prescribing a sector-wide reporting regime through the New Zealand Standards is in identifying the appropriate model to base the Standard on. To avoid the current problems with variation and inconsistency, the Standard would need to clearly specify the types and severity of harm and risk that would engage the reporting duty to apply across all health sector organisations. While it outside the scope of this paper to identify what those exact thresholds should be, it is suggested that such detail should be specified in the Government's proposed code of practice. This is discussed in more detail at subpart B below.

133 See Department of Social Welfare, above n 8, at 5, 20 and 36.

134 Standards Act 1988, s 10.

135 Standards New Zealand "About Us" (2012) Standards New Zealand <www.standards.co.nz>.

136 Health and Disability Services (Safety) Act 2011, ss 9 and 27. The current compulsory Standards for health services are NZS 8134.1:2008 and NZS 8134.0:2008.

137 For the Standard to be rendered compulsory it would only require approval by the Minister of Health: Health and Disability Services (Safety) Act, s 13. This power is subject to duties of consultation and analysis of public interest and cost under s 18 . 


\section{$B$ The Code of Practice}

As noted earlier, in its 2012 White Paper the Government proposes to introduce a legislative duty requiring all agencies that work with children to have child abuse intervention protocols. ${ }^{138}$ This is to be coupled with a national guideline code of practice that will inform the content of the individual agency protocols. ${ }^{139}$ This suggested structure appears to mirror the health sector's framework, with the code of practice serving the same function as the existing national guideline documents and the individual agency protocols apparently to be developed in the same ad hoc manner as the various health organisation protocols have been. This raises the risk that the problems found in the health sector's framework will be reproduced in the proposed national regime. Given that there is no discernable rationale for variations in intervention standards to exist across different regions or between different services or agencies, this surely should be avoided if the proposal is to be successful.

As such, it is suggested that the code of practice specify clear and uniform requirements to be contained in all individual agency protocols. Determining what those thresholds should be will require considerable inter-agency consultation, but on the basis of this article's analysis of the health sector's reporting regime, five specific areas should be standardised in the code. First, reporting obligations should be consistent across all agencies and services. This means that protocols should be uniform as to whether they compel reporting of identified or suspected child maltreatment or whether this is discretionary. Second, the definition of abuse ought to be uniform in all protocols. This is critical to ensuring that the type of behaviour categorised as maltreatment is universal and attracts the same standard of intervention. Third, the code of practice should specify whether or not the protocols extend to foetal protection. This will also require careful consideration of maternal autonomy. Fourth, the indicators of abuse that are used in identification procedures should be nationally consistent. Equally, the maltreatment indicia should be based on clear objective evidence rather than on subjective considerations such as the quality of a parent's personal relationships. Fifth, the code of practice should specify uniform thresholds for the levels of harm and risk that need to be present to trigger referral. These thresholds should also ideally correspond to the legislative standards for intervention.

\section{The Elephant in the Room: Skills Training}

Finally, it is recognised that an effective reporting regime is not a simple consequence of its technical form or the standards it imposes. ${ }^{140}$ Child abuse intervention protocols, no matter how

138 Ministry of Social Development, above n 16, at 81 and 165.

139 At 81 .

140 Russell Wills, Miranda Ritchie and Mollie Wilson "Improving detection and quality of assessment of child abuse and partner abuse is achievable with a formal organisational change approach" (2008) 44 JPCH 92 at 93. 
they are drafted, will be ineffective without personnel having the necessary training, time and skill to detect the subtle indicators of abuse that will engage them. A lack of training has been identified as one of the major impediments to child protection in the New Zealand health sector. ${ }^{141}$ Thus, improvements to the form of protocols alone will not be enough to improve the current reporting strategy and protect vulnerable children such as M. ${ }^{142}$ Rather, the development of an improved protocol framework must coincide with an increase in training to identify maltreatment. Without this, an improved referral regime risks operating in name only and may continue to fail vulnerable children and their families. As such, the realisation of the Government's stated commitment to increase child abuse identification training will be critical to the proposal's ultimate success or failure. $^{143}$

\section{CONCLUSION}

This article has demonstrated how the New Zealand health sector already operates under a detailed and wide-ranging protocol framework governing child abuse intervention. In many cases this regime imposes enforceable mandatory reporting duties on health practitioners. However, the framework contains a concerning level of inconsistency and variation that undermines its efficacy and may result in an intervention lottery for our most vulnerable children. As such, the article recommends rationalisation of the framework through a compulsory New Zealand Standard. In addition, the article suggests that the Government's recent proposal to enact an expanded protocolbased reporting regime in New Zealand take heed of these problems in order to avoid their replication on a larger scale. In particular, it suggests that the proposed code of practice be carefully devised to ensure a uniform approach to identification and referral of child abuse is taken nationally and across all sectors. Such reform is necessary to ensure that all New Zealand children are equally protected when engaging with the health system and other national services.

141 Fanslow, above n 19, at 27; Wills, Ritchie and Wilson, above n 140, at 93; Goodyear-Smith, above n 2, at 77.

142 The failure of the current reporting regime to protect M was discussed in Parts IV B3 and C5 above.

143 An increase in child abuse identification training is also proposed in the White Paper. See Ministry of Social Development, above n 1, at 7. 
VIII APPENDIX ONE: COMPARISON OF CHILD ABUSE REPORTING PROTOCOLS OPERATING IN THE NEW ZEALAND HEALTH SECTOR

\begin{tabular}{|c|c|c|c|c|}
\hline Protocol type & Mandatory obligation to report? & Definition of abuse ${ }^{144}$ & $\begin{array}{c}\text { Threshold of knowledge } \\
\text { required }\end{array}$ & Threshold of harm required \\
\hline $\begin{array}{l}\text { Child Youth and Family - } \\
\text { Interagency Guide "Working } \\
\text { Together to Keep Children and } \\
\text { Young People Safe" }\end{array}$ & $\begin{array}{l}\text { No. (Guide "to sit alongside" } \\
\text { agencies' internal child protection } \\
\text { policies). }\end{array}$ & $\begin{array}{l}\text { Statutory definition: "the harming } \\
\text { (whether physically, emotionally or } \\
\text { sexually), ill treatment, abuse, neglect } \\
\text { or deprivation of any child or young } \\
\text { person". } 145\end{array}$ & N/A & N/A \\
\hline $\begin{array}{l}\text { Memorandum of Understanding } \\
\text { between Child Youth and Family, } \\
\text { New Zealand Police and District } \\
\text { Health Boards. }{ }^{146}\end{array}$ & $\begin{array}{l}\text { Yes (explicit). Schedule One states } \\
\text { "the DHB will report their concerns } \\
\text { to CYF". }\end{array}$ & $\begin{array}{l}\text { No definition provided but individual } \\
\text { DHB policy definitions would apply as } \\
\text { specifies it is "to be implemented in } \\
\text { conjunction with the policies ... } \\
\text { relevant to each party". }\end{array}$ & Concern. & $\begin{array}{l}\text { "Immediate" risk to child or } \\
\text { "serious" injuries require report to } \\
\text { Police. All other "concerns" require } \\
\text { report to CYF. }\end{array}$ \\
\hline $\begin{array}{l}\text { MoH, Royal NZ College of General } \\
\text { Practitioners, NZ Medical } \\
\text { Association \& CYF "Recommended } \\
\text { referral process" }\end{array}$ & $\begin{array}{l}\text { No (implicit). Reporting is } \\
\text { discretionary (GP can "defer } \\
\text { reporting") and so the obligation is } \\
\text { voluntary not mandatory. }\end{array}$ & Not specified. & Suspicion. & $\begin{array}{l}\text { If "concerns about ... immediate } \\
\text { safety", report to Police. All other } \\
\text { concerns, report to CYF. }\end{array}$ \\
\hline
\end{tabular}

144 See Appendix Three for a detailed breakdown of child abuse definitions.

145 Children Young Persons and Their Families Act, s 2(1).

146 It is unclear how many DHBs have signed this Memorandum of Understanding. 


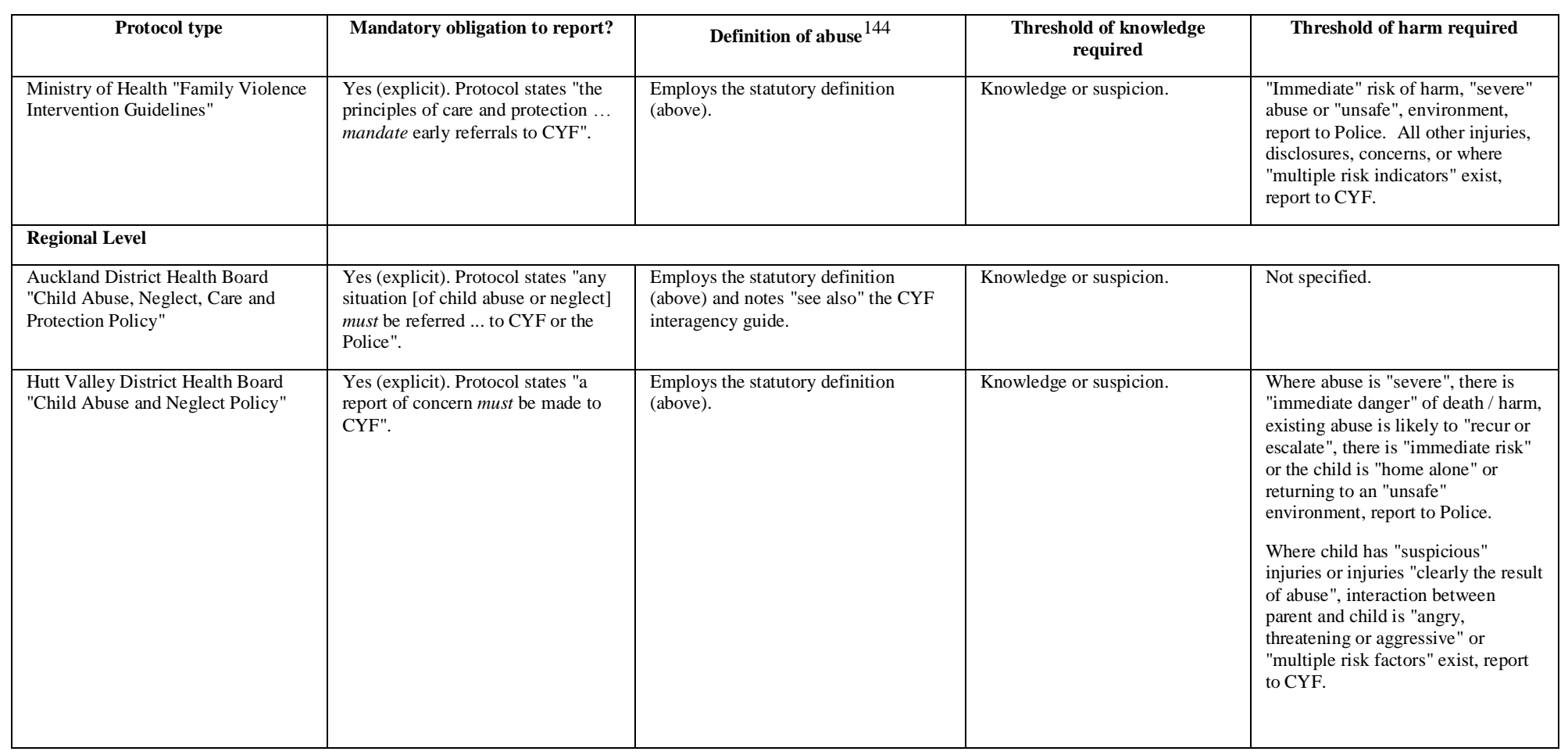




\begin{tabular}{|c|c|c|c|c|}
\hline Protocol type & Mandatory obligation to report? & Definition of abuse ${ }^{144}$ & $\begin{array}{l}\text { Threshold of knowledge } \\
\text { required }\end{array}$ & Threshold of harm required \\
\hline
\end{tabular}




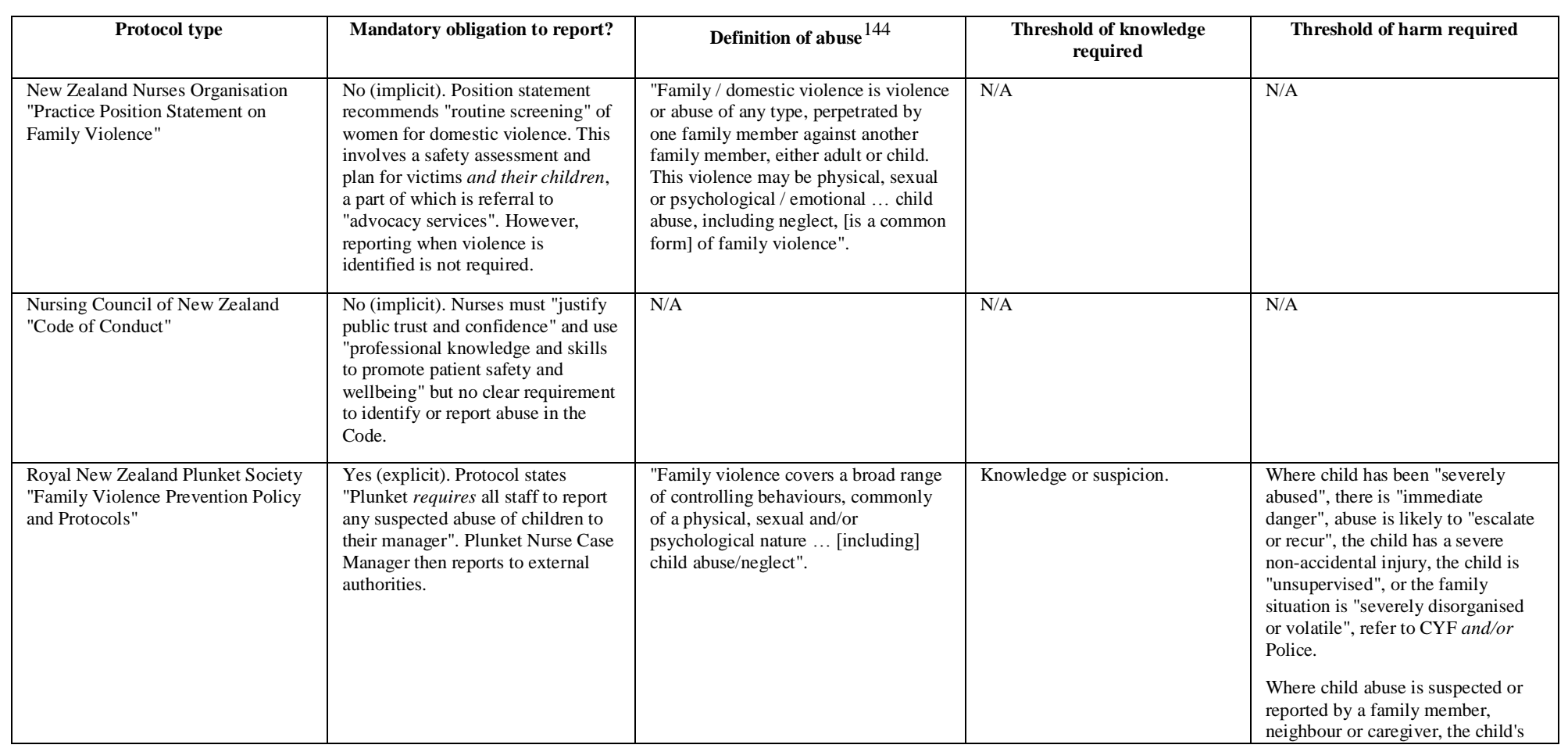




\begin{tabular}{|c|c|c|c|c|}
\hline Protocol type & Mandatory obligation to report? & Definition of abuse ${ }^{144}$ & $\begin{array}{l}\text { Threshold of knowledge } \\
\text { required }\end{array}$ & Threshold of harm required \\
\hline $\begin{array}{l}\text { New Zealand College of Midwives } \\
\text { "Position Statement on Family } \\
\text { Violence" }\end{array}$ & $\begin{array}{l}\text { No (explicit). Midwives "do not } \\
\text { support routine mandatory referral". } \\
\text { Routine screening for family } \\
\text { violence occurs; midwife may refer } \\
\text { where woman requests or when in } \\
\text { "midwife's professional judgment". }\end{array}$ & Not specified. & N/A & N/A \\
\hline $\begin{array}{l}\text { New Zealand Dental Association } \\
\text { Practice Guideline "Guidelines for } \\
\text { Child Protection" }\end{array}$ & $\begin{array}{l}\text { No (implicit). Protocol states that } \\
\text { dentists should report concerns of } \\
\text { abuse (rather than must report). }\end{array}$ & $\begin{array}{l}\text { Employs the statutory definition } \\
\text { (above). }\end{array}$ & Suspicion enough. & $\begin{array}{l}\text { Not specified for physical or sexual } \\
\text { abuse (presumably any level will } \\
\text { permit a report be made). However, } \\
\text { psychological abuse or neglect must } \\
\text { be "serious". }\end{array}$ \\
\hline $\begin{array}{l}\text { New Zealand Association of } \\
\text { Counsellors "Policy Manual" }\end{array}$ & $\begin{array}{l}\text { No (implicit). Protocol states that } \\
\text { counsellor has discretion to report } \\
\text { (on the basis of their professional } \\
\text { judgment, after balancing the risk of } \\
\text { harm and the negative impact on the } \\
\text { therapeutic relationship). }\end{array}$ & Not specified. & $\begin{array}{l}\text { Suspicion enough, but must be } \\
\text { "on reasonable grounds". }\end{array}$ & $\begin{array}{l}\text { A "clear and imminent danger" to } \\
\text { the client or another is required. It is } \\
\text { noted that a "present or imminent } \\
\text { risk of abuse" would satisfy that } \\
\text { requirement. }\end{array}$ \\
\hline $\begin{array}{l}\text { New Zealand College of Clinical } \\
\text { Psychologists "Code of Ethics" }\end{array}$ & $\begin{array}{l}\text { No (implicit). The Code specifies a } \\
\text { "duty to disclose" information in } \\
\text { situations where there is a "threat to } \\
\text { safety", but this is not mandatory. }\end{array}$ & Not specified. & Not specified. & $\begin{array}{l}\text { A "significant" health, safety and / } \\
\text { or relationship issue. }\end{array}$ \\
\hline
\end{tabular}




\begin{tabular}{|c|c|c|c|c|}
\hline Protocol type & Mandatory obligation to report? & Definition of abuse ${ }^{144}$ & $\begin{array}{c}\text { Threshold of knowledge } \\
\text { required }\end{array}$ & Threshold of harm required \\
\hline \multicolumn{5}{|l|}{ Individual Hospitals } \\
\hline $\begin{array}{l}\text { Wakefield Health Limited (trading as } \\
\text { Wakefield Hospital) "Policy: Abuse } \\
\text { and Neglect" }\end{array}$ & $\begin{array}{l}\text { No (implicit). Protocol states "in } \\
\text { cases of suspected abuse of a child } \\
\ldots \text { staff should discuss the matter } \\
\text { with the Hospital Manager" (rather } \\
\text { than shall as used for patient abuse } \\
\text { by hospital employees). }\end{array}$ & $\begin{array}{l}\text { Any situation "when a person } \\
\text { experiences harmful physical, mental, } \\
\text { sexual, material and social effects } \\
\text { caused by another person or persons". }\end{array}$ & Suspicion enough. & Not specified. \\
\hline
\end{tabular}




\section{APPENDIX TWO: COMPARISON OF IDENTIFICATION AND REPORTING PROCESSES REQUIRED IN THE}

PROTOCOLS

\begin{tabular}{|c|c|c|c|c|c|}
\hline Protocol & Identification & Consultation required? & Risk assessment? & Documentation? & Report to? \\
\hline \multicolumn{6}{|l|}{ National Level } \\
\hline $\begin{array}{l}\text { Child Youth and Family - } \\
\text { Interagency Guide "Working } \\
\text { Together to Keep Children and } \\
\text { Young People Safe" }\end{array}$ & $\begin{array}{l}\text { Comprehensive list of symptoms } \\
\text { specified for each category of } \\
\text { abuse, including the positions and } \\
\text { patterns of marks, bruises and } \\
\text { burns which indicate non- } \\
\text { accidental infliction of injury, and } \\
\text { particular behavioural indicators. }\end{array}$ & Not specified. & Not specified. & Not specified. & Not specified. \\
\hline $\begin{array}{l}\text { Memorandum of Understanding } \\
\text { between Child Youth and } \\
\text { Family, New Zealand Police and } \\
\text { District Health Boards. }\end{array}$ & Not specified. & $\begin{array}{l}\text { Consultation "early and often" } \\
\text { required in accordance with internal } \\
\text { DHB policy (no additional } \\
\text { requirement imposed). }\end{array}$ & $\begin{array}{l}\text { "Primary assessment of risk" } \\
\text { required once concern } \\
\text { identified (but no detail on } \\
\text { what this should involve). }\end{array}$ & $\begin{array}{l}\text { Careful documentation of } \\
\text { "concerns and findings" } \\
\text { required in accordance with } \\
\text { internal DHB policy (no } \\
\text { additional requirement } \\
\text { imposed). }\end{array}$ & $\begin{array}{l}\text { CYF (in all instances of concern). } \\
\text { Discretionary ability to make } \\
\text { additional report to Police. }\end{array}$ \\
\hline $\begin{array}{l}\text { MoH, Royal NZ College of } \\
\text { General Practitioners, NZ } \\
\text { Medical Association \& CYF } \\
\text { "Recommended referral process" }\end{array}$ & $\begin{array}{l}\text { Annexes "signs of abuse and } \\
\text { neglect" (as per Ministry of } \\
\text { Health Family Violence } \\
\text { Intervention Guidelines). }\end{array}$ & $\begin{array}{l}\text { Recommendation that "multi } \\
\text { disciplinary expertise is sought". }\end{array}$ & Not specified. & $\begin{array}{l}\text { Required: "it is essential to } \\
\text { adequately document the } \\
\text { history and clinical signs of } \\
\text { injury". }\end{array}$ & $\begin{array}{l}\text { CYF or Police (depending on } \\
\text { level of harm or risk). }\end{array}$ \\
\hline $\begin{array}{l}\text { Ministry of Health "Family } \\
\text { Violence Intervention } \\
\text { Guidelines" }\end{array}$ & $\begin{array}{l}\text { Sets out specific indicators for } \\
\text { "high risk groups" and "signs and } \\
\text { symptoms of abuse and neglect". } \\
\text { Where indicators are present, } \\
\text { questioning / physical } \\
\text { examination is required. }\end{array}$ & $\begin{array}{l}\text { Preliminary consultation with CYF } \\
\text { recommended (before formal } \\
\text { notification made). Internal } \\
\text { consultation also recommended to } \\
\text { determine level of risk posed and } \\
\text { appropriate response. }\end{array}$ & $\begin{array}{l}\text { Multidisciplinary team should } \\
\text { conduct assessment to identify } \\
\text { level of risk posed to patient. }\end{array}$ & $\begin{array}{l}\text { All injury sites (both old and } \\
\text { new) to be marked and } \\
\text { described in detail on a } \\
\text { "body map". Patient } \\
\text { explanation of when and } \\
\text { how injuries occurred to be }\end{array}$ & $\begin{array}{l}\text { CYF or Police (depending on } \\
\text { level of risk identified in risk } \\
\text { assessment). }\end{array}$ \\
\hline
\end{tabular}




\begin{tabular}{|c|c|c|c|c|c|}
\hline Protocol & Identification & Consultation required? & Risk assessment? & Documentation? & Report to? \\
\hline & & & & $\begin{array}{l}\text { noted. Clinician opinion of } \\
\text { whether explanation is } \\
\text { consistent with physical } \\
\text { indicators should be noted. }\end{array}$ & \\
\hline \multicolumn{6}{|l|}{ Regional Level } \\
\hline $\begin{array}{l}\text { Auckland District Health Board } \\
\text { "Child Abuse, Neglect, Care and } \\
\text { Protection Policy" }\end{array}$ & $\begin{array}{l}\text { Requirement to be "aware of } \\
\text { signs of abuse" and "risk factors". } \\
\text { These not specified in the policy } \\
\text { but noted as "covered in } \\
\text { training". }\end{array}$ & $\begin{array}{l}\text { Internal consultation required unless } \\
\text { the child is in "immediate danger". }\end{array}$ & $\begin{array}{l}\text { Not specified, but consultation } \\
\text { should include analysis of the } \\
\text { severity of abuse, child's } \\
\text { immediate safety, parental } \\
\text { stress factors etc. }\end{array}$ & $\begin{array}{l}\text { Documentation of any } \\
\text { marks of injuries observed } \\
\text { required. }\end{array}$ & $\begin{array}{l}\text { CYF or the Police (depending on } \\
\text { level of risk identified). }\end{array}$ \\
\hline $\begin{array}{l}\text { Hutt Valley District Health } \\
\text { Board "Child Abuse and Neglect } \\
\text { Policy" }\end{array}$ & $\begin{array}{l}\text { Notes that this can either be } \\
\text { through disclosure or recognising } \\
\text { signs. } \\
\text { "Signs and symptoms of abuse" } \\
\text { and "High Risk Indicators" } \\
\text { annexed (per the Ministry of } \\
\text { Health Family Violence } \\
\text { Intervention Guidelines). }\end{array}$ & $\begin{array}{l}\text { Internal consultation "at least once" } \\
\text { required. }\end{array}$ & $\begin{array}{l}\text { Required wherever child abuse } \\
\text { identified or suspected to } \\
\text { "ascertain the level of risk to } \\
\text { the [child's] health and safety". }\end{array}$ & $\begin{array}{l}\text { "Accurate informative } \\
\text { documentation" required in } \\
\text { all cases but no detail } \\
\text { provided of what should be } \\
\text { included. }\end{array}$ & $\begin{array}{l}\text { CYF or the Police (depending on } \\
\text { the level of risk identified in the } \\
\text { risk assessment). }\end{array}$ \\
\hline $\begin{array}{l}\text { Capital and Coast District Health } \\
\text { Board "Family Violence } \\
\text { Intervention Policy, Procedures } \\
\text { and Protocols" }\end{array}$ & $\begin{array}{l}\text { Requirement to consider child } \\
\text { abuse as a differential diagnosis } \\
\text { when disclosed or identification } \\
\text { through signs and symptoms. } \\
\text { "Signs and symptoms of abuse" } \\
\text { and "High Risk Indicators" } \\
\text { annexed (per the Ministry of } \\
\text { Health Family Violence } \\
\text { Intervention Guidelines). }\end{array}$ & $\begin{array}{l}\text { Required "at least once" with } \\
\text { specified persons, including on-call } \\
\text { paediatrician. }\end{array}$ & $\begin{array}{l}\text { Required. Refers to the "High } \\
\text { Risk Indicators". Specifies } \\
\text { additional "family", } \\
\text { "historical" and "other" factors, } \\
\text { as well as "red flags" that } \\
\text { indicate high risk. }\end{array}$ & $\begin{array}{l}\text { All "observations, } \\
\text { assessment and } \\
\text { management" must be } \\
\text { documented thoroughly, but } \\
\text { no detailed requirements of } \\
\text { what this should include. }\end{array}$ & $\begin{array}{l}\text { CYF or the Police (depending on } \\
\text { the level of risk identified in the } \\
\text { risk assessment). Also the } \\
\text { CCDHB Child Protection } \\
\text { Coordinator. }\end{array}$ \\
\hline
\end{tabular}




\begin{tabular}{|c|c|c|c|c|c|}
\hline Protocol & Identification & Consultation required? & Risk assessment? & Documentation? & Report to? \\
\hline \multicolumn{6}{|l|}{ Professional Associations } \\
\hline $\begin{array}{l}\text { Medical Council "Good Medical } \\
\text { Practice" }\end{array}$ & $\begin{array}{l}\text { Requirement to "adequately } \\
\text { assess patient's condition" (but no } \\
\text { indicators provided). }\end{array}$ & $\begin{array}{l}\text { Not specified, but implicit in } \\
\text { requirement to "work with } \\
\text { colleagues". }\end{array}$ & Not specified. & Not specified. & Not specified. \\
\hline $\begin{array}{l}\text { New Zealand Nurses } \\
\text { Organisation "Practice Position } \\
\text { Statement on Family Violence" }\end{array}$ & $\begin{array}{l}\text { Routine screening for family } \\
\text { violence recommended, but no } \\
\text { detail provided as to indicators. }\end{array}$ & Not specified. & $\begin{array}{l}\text { "Safety assessment" } \\
\text { recommended as part of } \\
\text { routine screening for family } \\
\text { violence, but no detail } \\
\text { provided. }\end{array}$ & Not specified. & $\begin{array}{l}\text { Referral to "appropriate advocacy } \\
\text { services" recommended. }\end{array}$ \\
\hline $\begin{array}{l}\text { Nursing Council of New Zealand } \\
\text { "Code of Conduct" }\end{array}$ & N/A & N/A & N/A & N/A & N/A \\
\hline $\begin{array}{l}\text { Royal New Zealand Plunket } \\
\text { Society "Family Violence } \\
\text { Intervention Policy and } \\
\text { Protocols" }\end{array}$ & $\begin{array}{l}\text { At every "core contact" with } \\
\text { client, "screening questions" } \\
\text { should be asked to identify } \\
\text { whether abuse or neglect a } \\
\text { possibility. Requirement to } \\
\text { "observe" environment for } \\
\text { indicators (provides a list of } \\
\text { such). }\end{array}$ & $\begin{array}{l}\text { Initial consultation with clinical } \\
\text { leader required in all cases. }\end{array}$ & $\begin{array}{l}\text { Risk assessment using } \\
\text { "Manitoba Risk Assessment } \\
\text { Model" required. } \\
\text { Identification one of three } \\
\text { categories of risk required: } \\
\text { "critical"; "urgent / semi- } \\
\text { urgent"; or "at risk". }\end{array}$ & $\begin{array}{l}\text { Requirement to "record your } \\
\text { observations clearly, } \\
\text { including any injuries". }\end{array}$ & $\begin{array}{l}\text { Internal manager (by any staff } \\
\text { member or volunteer who } \\
\text { suspects abuse). } \\
\text { CYF or Police (by Plunket Nurse } \\
\text { Case Manager) depending on } \\
\text { level of risk identified. }\end{array}$ \\
\hline $\begin{array}{l}\text { New Zealand College of } \\
\text { Midwives "Midwives Handbook } \\
\text { for Practice" }\end{array}$ & $\begin{array}{l}\text { Routine screening for family } \\
\text { violence should occur at } 30 \text { week } \\
\text { gestation. No clear indicators } \\
\text { provided. }\end{array}$ & Not specified. & Not specified. & Not specified. & Not specified. \\
\hline $\begin{array}{l}\text { New Zealand Dental Association } \\
\text { "Guidelines for Child Protection" }\end{array}$ & Not specified. & $\begin{array}{l}\text { Only required if practitioner works } \\
\text { for a DHB. If so, must consult with } \\
\text { the paediatrician on duty. }\end{array}$ & Not specified. & $\begin{array}{l}\text { Required, but no detail } \\
\text { specified. }\end{array}$ & $\begin{array}{l}\text { CYF or Police (but no guidance } \\
\text { on when each should be } \\
\text { engaged). }\end{array}$ \\
\hline
\end{tabular}




\begin{tabular}{|c|c|c|c|c|c|}
\hline Protocol & Identification & Consultation required? & Risk assessment? & Documentation? & Report to? \\
\hline $\begin{array}{l}\text { New Zealand Association of } \\
\text { Counsellors "Policy Manual" }\end{array}$ & Not specified. & "Encouraged" but not required. & Not specified. & Not specified. & To "responsible authorities". \\
\hline $\begin{array}{l}\text { New Zealand College of Clinical } \\
\text { Psychologists "Code of Ethics" }\end{array}$ & Not specified. & $\begin{array}{l}\text { Psychologists "should" consult with } \\
\text { senior colleagues. }\end{array}$ & Not specified. & Not specified. & To "appropriate people". \\
\hline $\begin{array}{l}\text { Australasian College for } \\
\text { Emergency Medicine "Policy on } \\
\text { Child at Risk" }\end{array}$ & $\begin{array}{l}\text { Abuse should be considered in } \\
\text { differential diagnosis wherever } \\
\text { child presents with "injury, } \\
\text { failure to thrive or behavioural } \\
\text { problems". }\end{array}$ & Not specified. & Not specified. & $\begin{array}{l}\text { "Appropriate } \\
\text { documentation" required, } \\
\text { but no detail specified. }\end{array}$ & Not specified. \\
\hline \multicolumn{6}{|l|}{ Individual Hospitals } \\
\hline $\begin{array}{l}\text { Starship Hospital "Children's } \\
\text { Health Clinical Guideline" }\end{array}$ & $\begin{array}{l}\text { All childhood injuries require a } \\
\text { "clear and highly detailed } \\
\text { history". A list of factors is } \\
\text { provided that, if present, require } \\
\text { child abuse to be included in the } \\
\text { differential diagnosis. }\end{array}$ & $\begin{array}{l}\text { Internal consultation required } \\
\text { initially. Following this, } \\
\text { consultation with Auckland DHB } \\
\text { child protection team "Te } \\
\text { Puaruruhau" required. }\end{array}$ & $\begin{array}{l}\text { Not specified, however Te } \\
\text { Puaruruhau conducts an } \\
\text { assessment of the child } \\
\text { following internal referral. }\end{array}$ & $\begin{array}{l}\text { Diagrams of all bruising and } \\
\text { external injuries required, } \\
\text { including description of } \\
\text { patterns of injury, colour, } \\
\text { shape, outline and size of } \\
\text { bruises. }\end{array}$ & $\begin{array}{l}\text { CYF or Police (depending on } \\
\text { level of risk). Also primary } \\
\text { healthcare providers to be } \\
\text { notified and (by discretion) ACC. }\end{array}$ \\
\hline $\begin{array}{l}\text { Wakefield Health Limited } \\
\text { (trading as Wakefield Hospital) } \\
\text { "Policy: Abuse and Neglect" }\end{array}$ & Not specified. & $\begin{array}{l}\text { Internal consultation with hospital } \\
\text { manager or nurse manager required } \\
\text { and external consultation ("a } \\
\text { confidential discussion") with the } \\
\text { child's General Practitioner. }\end{array}$ & Not specified. & $\begin{array}{l}\text { "Incident form" to be } \\
\text { completed. }\end{array}$ & Police or "social worker". \\
\hline $\begin{array}{l}\text { Southern Cross Hospitals } \\
\text { National "Prevention of Patient } \\
\text { Abuse, Neglect or Maltreatment" }\end{array}$ & $\begin{array}{l}\text { During "patient assessment", } \\
\text { should consider physical } \\
\text { appearance and behavioural } \\
\text { indicators for possible abuse (lists } \\
\text { unique indicators). }\end{array}$ & $\begin{array}{l}\text { Not specified, but the Ministry of } \\
\text { Health Family Violence National } \\
\text { Call Centre telephone number is } \\
\text { listed. }\end{array}$ & $\begin{array}{l}\text { Not specified, but notes a } \\
\text { "medical and social } \\
\text { assessment" is required. }\end{array}$ & $\begin{array}{l}\text { "Documentation in the } \\
\text { patient's hospital clinical } \\
\text { record" required, but no } \\
\text { detail on what should be } \\
\text { included provided. }\end{array}$ & $\begin{array}{l}\text { First, to Hospital Manager and } \\
\text { patient's Medical Specialist. } \\
\text { Manager or Specialist will report } \\
\text { to the "appropriate external or } \\
\text { internal authority". }\end{array}$ \\
\hline
\end{tabular}


APPENDIX THREE: COMPARISON OF THE DEFINITIONS OF CHILD ABUSE USED IN THE PROTOCOLS

\begin{tabular}{|c|c|c|c|c|c|}
\hline Protocol & General definition & Physical Abuse & Emotional / Psychological Abuse & Sexual Abuse & Neglect \\
\hline \multicolumn{6}{|l|}{ National Level } \\
\hline $\begin{array}{l}\text { Child Youth and Family - } \\
\text { Interagency Guide "Working } \\
\text { Together to Keep Children and } \\
\text { Young People Safe" }\end{array}$ & $\begin{array}{l}\text { Statutory definition: "the } \\
\text { harming (whether physically, } \\
\text { emotionally or sexually), ill } \\
\text { treatment, abuse, neglect or } \\
\text { deprivation of any child or } \\
\text { young person". }\end{array}$ & $\begin{array}{l}\text { Any behaviour which results } \\
\text { in physical harm to a child. }\end{array}$ & $\begin{array}{l}\text { A pattern of behaviour where the } \\
\text { child is rejected and put down. They } \\
\text { may be isolated, constantly degraded } \\
\text { and criticised or negatively } \\
\text { compared to others. }\end{array}$ & $\begin{array}{l}\text { Any act where an adult or a } \\
\text { more powerful person uses a } \\
\text { child or young person for a } \\
\text { sexual purpose } \ldots \text { may include } \\
\text { physical sexual acts or ... } \\
\text { exposure to pornographic } \\
\text { material and internet sites or } \\
\text { sexual conversation. }\end{array}$ & $\begin{array}{l}\text { Can consist of physical neglect } \\
\text { (not providing the necessities of } \\
\text { life); neglectful supervision; } \\
\text { emotional neglect (not giving } \\
\text { children comfort, attention and } \\
\text { love); medical neglect; } \\
\text { educational neglect. }\end{array}$ \\
\hline $\begin{array}{l}\text { Memorandum of Understanding } \\
\text { between Child Youth and } \\
\text { Family, New Zealand Police and } \\
\text { District Health Boards }\end{array}$ & $\begin{array}{l}\text { Not specified (but in practice } \\
\text { would engage the DHB } \\
\text { definitions). }\end{array}$ & Not specified. & Not specified. & Not specified. & Not specified. \\
\hline $\begin{array}{l}\text { MOH, Royal NZ College of } \\
\text { General Practitioners, NZMA } \\
\text { and CYF "Recommended } \\
\text { referral process for General } \\
\text { Practitioners: Suspected Child } \\
\text { Abuse and Neglect" }\end{array}$ & Not specified. & Not specified. & Not specified. & Not specified. & Not specified. \\
\hline $\begin{array}{l}\text { Ministry of Health "Family } \\
\text { Violence Intervention } \\
\text { Guidelines" }\end{array}$ & Statutory definition (above). & $\begin{array}{l}\text { Any act that may result in } \\
\text { inflicted injury. }\end{array}$ & $\begin{array}{l}\text { Any act or omission that results in } \\
\text { impaired psychological, social, } \\
\text { intellectual or emotional functioning } \\
\text { and development. It may include } \\
\text { rejection, isolation, oppression, } \\
\text { deprivation of affection or cognitive } \\
\text { stimulation, inappropriate and }\end{array}$ & $\begin{array}{l}\text { Any act or acts that result in } \\
\text { sexual exploitation whether } \\
\text { consensual or not. It may } \\
\text { include non-contact abuse } \\
\text { (exhibitionism, voyeurism, } \\
\text { suggestive behaviour or } \\
\text { exposure to pornographic }\end{array}$ & $\begin{array}{l}\text { Any act or omission that results } \\
\text { in impaired physical } \\
\text { functioning, injury and/or } \\
\text { development of a child. May } \\
\text { include physical neglect (failure } \\
\text { to provide the necessities to } \\
\text { sustain life or health); neglectful }\end{array}$ \\
\hline
\end{tabular}




\begin{tabular}{|c|c|c|c|c|c|}
\hline Protocol & General definition & Physical Abuse & Emotional / Psychological Abuse & Sexual Abuse & Neglect \\
\hline & & & $\begin{array}{l}\text { continued criticism, threats, } \\
\text { humiliation, accusations, } \\
\text { inappropriate expectations, exposure } \\
\text { to family violence, illegal or anti- } \\
\text { social activities, parent's mental / } \\
\text { emotional condition or substance } \\
\text { abuse of a household member. }\end{array}$ & $\begin{array}{l}\text { material) or contact abuse } \\
\text { (direct sexual abuse). }\end{array}$ & $\begin{array}{l}\text { supervision; medical neglect; } \\
\text { abandonment; refusal to assume } \\
\text { parental responsibility. }\end{array}$ \\
\hline \multicolumn{6}{|l|}{ Regional Level } \\
\hline $\begin{array}{l}\text { Auckland District Health Board } \\
\text { "Child Abuse, Neglect, Care and } \\
\text { Protection Policy" }\end{array}$ & Statutory definition (above). & Not specified. & Not specified. & Not specified. & Not specified. \\
\hline $\begin{array}{l}\text { Hutt Valley District Health } \\
\text { Board "Child Abuse and Neglect } \\
\text { Policy" }\end{array}$ & Statutory definition (above). & $\begin{array}{l}\text { Same as Ministry of Health } \\
\text { "Family Violence } \\
\text { Intervention Guidelines" } \\
\text { (above). }\end{array}$ & $\begin{array}{l}\text { Same as Ministry of Health "Family } \\
\text { Violence Intervention Guidelines" } \\
\text { (above). }\end{array}$ & $\begin{array}{l}\text { Same as Ministry of Health } \\
\text { "Family Violence Intervention } \\
\text { Guidelines" (above). }\end{array}$ & $\begin{array}{l}\text { Same as Ministry of Health } \\
\text { "Family Violence Intervention } \\
\text { Guidelines" (above). }\end{array}$ \\
\hline $\begin{array}{l}\text { Capital and Coast District Health } \\
\text { Board "Family Violence } \\
\text { Intervention Policy, Procedures } \\
\text { and Protocols" }\end{array}$ & Statutory definition (above). & $\begin{array}{l}\text { Same as Ministry of Health } \\
\text { "Family Violence } \\
\text { Intervention Guidelines" } \\
\text { (above). }\end{array}$ & $\begin{array}{l}\text { Same as Ministry of Health "Family } \\
\text { Violence Intervention Guidelines" } \\
\text { (above). }\end{array}$ & $\begin{array}{l}\text { Same as Ministry of Health } \\
\text { "Family Violence Intervention } \\
\text { Guidelines" (above). }\end{array}$ & $\begin{array}{l}\text { Same as Ministry of Health } \\
\text { "Family Violence Intervention } \\
\text { Guidelines" (above). }\end{array}$ \\
\hline \multicolumn{6}{|l|}{ Professional Associations } \\
\hline $\begin{array}{l}\text { Medical Council "Good Medical } \\
\text { Practice" }\end{array}$ & Not specified. & Not specified. & Not specified. & Not specified. & Not specified. \\
\hline $\begin{array}{l}\text { New Zealand Nurses } \\
\text { Organisation "Practice Position } \\
\text { Statement on Family Violence" }\end{array}$ & Not specified. & Not specified. & Not specified. & Not specified. & Not specified. \\
\hline
\end{tabular}




\begin{tabular}{|c|c|c|c|c|c|}
\hline Protocol & General definition & Physical Abuse & Emotional / Psychological Abuse & Sexual Abuse & Neglect \\
\hline $\begin{array}{l}\text { Nursing Council of New Zealand } \\
\text { "Code of Conduct" }\end{array}$ & N/A & N/A & N/A & N/A & N/A \\
\hline $\begin{array}{l}\text { Royal New Zealand Plunket } \\
\text { Society "Family Violence } \\
\text { Prevention Policy and Protocols" }\end{array}$ & Not specified. & Not specified. & Not specified. & Not specified. & Not specified. \\
\hline $\begin{array}{l}\text { New Zealand College of } \\
\text { Midwives "Position Statement on } \\
\text { Family Violence" }\end{array}$ & Not specified. & Not specified. & Not specified. & Not specified. & Not specified. \\
\hline $\begin{array}{l}\text { New Zealand Dental Association } \\
\text { Practice Guideline "Guidelines } \\
\text { for Child Protection" }\end{array}$ & Statutory definition (above). & $\begin{array}{l}\text { "Unexplained repetitive } \\
\text { bruises, lacerations, abrasions, } \\
\text { fractures or burns". }\end{array}$ & $\begin{array}{l}\text { Rejection, deprivation of stimulation } \\
\text { or affection, constant criticism or } \\
\text { exposure to family violence. } \\
\text { However, must be "serious" to } \\
\text { constitute child abuse. }\end{array}$ & Not specified. & $\begin{array}{l}\text { Failure, by parents, guardians or } \\
\text { usual caregivers, to provide for } \\
\text { the child's appropriate physical, } \\
\text { emotional or medical needs. } \\
\text { The child's health, development } \\
\text { or safety is endangered. } \\
\text { However, must be "serious" to } \\
\text { constitute child abuse. }\end{array}$ \\
\hline $\begin{array}{l}\text { New Zealand Association of } \\
\text { Counsellors "Policy Manual" }\end{array}$ & Not specified. & Not specified. & Not specified. & Not specified. & Not specified. \\
\hline $\begin{array}{l}\text { New Zealand College of Clinical } \\
\text { Psychologists "Code of Ethics" }\end{array}$ & Not specified. & Not specified. & Not specified. & Not specified. & Not specified. \\
\hline $\begin{array}{l}\text { Australasian College for } \\
\text { Emergency Medicine "Policy on } \\
\text { Child at Risk" }\end{array}$ & $\begin{array}{l}\text { Either "significant harm" or } \\
\text { the risk of such caused by the } \\
\text { act or omission of an adult. }\end{array}$ & Not specified. & Not specified. & Not specified. & Not specified. \\
\hline
\end{tabular}




\begin{tabular}{|c|c|c|c|c|c|}
\hline Protocol & General definition & Physical Abuse & Emotional / Psychological Abuse & Sexual Abuse & Neglect \\
\hline \multicolumn{6}{|l|}{ Individual Hospitals } \\
\hline $\begin{array}{l}\text { Starship Hospital "Children's } \\
\text { Health Clinical Guideline" }\end{array}$ & Not specified. & $\begin{array}{l}\text { Non-accidental injury or } \\
\text { violence. }\end{array}$ & $\begin{array}{l}\text { May include exposure to family } \\
\text { violence, even when it does not } \\
\text { result in physical harm. }\end{array}$ & Not specified. & $\begin{array}{l}\text { The failure of caregivers to } \\
\text { provide adequately for the } \\
\text { health, safety and wellbeing of a } \\
\text { child or young person. }\end{array}$ \\
\hline $\begin{array}{l}\text { Wakefield Health Limited } \\
\text { (trading as Wakefield Hospital) } \\
\text { "Policy: Abuse and Neglect" }\end{array}$ & $\begin{array}{l}\text { Harmful physical, mental, } \\
\text { sexual, material and social } \\
\text { effects caused by another } \\
\text { person or persons. }\end{array}$ & $\begin{array}{l}\text { Infliction of physical pain, } \\
\text { injury or force. }\end{array}$ & $\begin{array}{l}\text { Behaviour that causes mental or } \\
\text { emotional anguish or fear. }\end{array}$ & $\begin{array}{l}\text { Sexually abusive and } \\
\text { exploitative behaviours } \\
\text { involving threats, force or the } \\
\text { inability of the person to give } \\
\text { consent. }\end{array}$ & $\begin{array}{l}\text { Includes physical neglect } \\
\text { (failure to provide adequate } \\
\text { food, shelter, clothing or } \\
\text { protection); wilfully denying a } \\
\text { person assistance and thereby } \\
\text { exposing that person to the risk } \\
\text { of harm; or emotional neglect } \\
\text { (restricting the social, } \\
\text { intellectual and emotional } \\
\text { growth or wellbeing of a } \\
\text { person). }\end{array}$ \\
\hline $\begin{array}{l}\text { Southern Cross Hospitals } \\
\text { National "Prevention of Patient } \\
\text { Abuse, Neglect or Maltreatment" }\end{array}$ & $\begin{array}{l}\text { The wilful infliction of } \\
\text { physical pain, injury or } \\
\text { debilitating mental anguish, } \\
\text { unreasonable confinement or } \\
\text { wilful deprivation of services. }\end{array}$ & Not specified. & Not specified. & $\begin{array}{l}\text { Molestation or relations with a } \\
\text { patient or the encouragement of } \\
\text { the same with a patient. Includes } \\
\text { intentional touching, sexual } \\
\text { relations or sexual dialogue. }\end{array}$ & $\begin{array}{l}\text { Failure to provide the level of } \\
\text { services, care, or medical } \\
\text { treatment necessary to maintain } \\
\text { (a patient's) physical, mental, } \\
\text { emotional and spiritual health. }\end{array}$ \\
\hline
\end{tabular}


XI APPENDIX FOUR: INDEX OF ALL PROTOCOLS REVIEWED

\begin{tabular}{|c|c|c|c|}
\hline Organisation & Protocol / Policy Title & $\begin{array}{l}\text { Policy / Document } \\
\text { Reference }\end{array}$ & Date \\
\hline \multicolumn{4}{|l|}{ National Level } \\
\hline Child Youth and Family & $\begin{array}{l}\text { An interagency guide: } \\
\text { Working Together to Keep } \\
\text { Children and Young People } \\
\text { Safe }\end{array}$ & CYF045 & February 2011 \\
\hline $\begin{array}{l}\text { Child Youth and Family, } \\
\text { New Zealand Police, and } \\
\text { [individual] District } \\
\text { Health Board }\end{array}$ & $\begin{array}{l}\text { Memorandum of } \\
\text { Understanding }\end{array}$ & & August 2011 \\
\hline $\begin{array}{l}\text { Ministry of Health, Royal } \\
\text { NZ College of General } \\
\text { Practitioners, NZ } \\
\text { Medical Association and } \\
\text { Child Youth and Family }\end{array}$ & $\begin{array}{l}\text { Recommended Referral } \\
\text { Process for GPs: Suspected } \\
\text { Child Abuse and Neglect }\end{array}$ & & December 2000 \\
\hline Ministry of Health & $\begin{array}{l}\text { Family Violence Intervention } \\
\text { Guidelines: Child and Partner } \\
\text { Abuse }\end{array}$ & & 2002 \\
\hline \multicolumn{4}{|l|}{ Regional Level } \\
\hline $\begin{array}{l}\text { Auckland District Health } \\
\text { Board }\end{array}$ & $\begin{array}{l}\text { Child Abuse, Neglect, Care } \\
\text { and Protection Policy }\end{array}$ & PP01/PCR/002 & May 2011 \\
\hline $\begin{array}{l}\text { Capital and Coast District } \\
\text { Health Board }\end{array}$ & $\begin{array}{l}\text { Family Violence Intervention } \\
\text { Policy, Procedures and } \\
\text { Protocols }\end{array}$ & ID 1.1154 & 09 August 2010 \\
\hline $\begin{array}{l}\text { Hutt Valley District } \\
\text { Health Board }\end{array}$ & $\begin{array}{l}\text { Child Abuse and Neglect } \\
\text { Policy }\end{array}$ & VIP.001 & December 2011 \\
\hline \multicolumn{4}{|l|}{ Professional Associations } \\
\hline $\begin{array}{l}\text { Australasian College for } \\
\text { Emergency Medicine }\end{array}$ & Policy on Child at Risk & P35 & July 2005 \\
\hline $\begin{array}{l}\text { New Zealand Association } \\
\text { of Counsellors }\end{array}$ & $\begin{array}{l}\text { Policy Manual: Reporting } \\
\text { Possible Child Abuse }\end{array}$ & & October 1992 \\
\hline $\begin{array}{l}\text { Royal New Zealand } \\
\text { Plunket Society }\end{array}$ & $\begin{array}{l}\text { Family Violence Prevention } \\
\text { Policy and Protocols }\end{array}$ & & July 2008 \\
\hline $\begin{array}{l}\text { Medical Council of New } \\
\text { Zealand }\end{array}$ & $\begin{array}{l}\text { Good Medical Practice: A } \\
\text { Guide for Doctors }\end{array}$ & & June 2008 \\
\hline $\begin{array}{l}\text { New Zealand College of } \\
\text { Midwives }\end{array}$ & $\begin{array}{l}\text { Midwives Handbook for } \\
\text { Practice (Fourth Edition) }\end{array}$ & & 2008 \\
\hline $\begin{array}{l}\text { New Zealand College of } \\
\text { Midwives }\end{array}$ & $\begin{array}{l}\text { Consensus Statement on } \\
\text { Family Violence }\end{array}$ & & 2002 \\
\hline
\end{tabular}




\begin{tabular}{|c|c|c|c|}
\hline $\begin{array}{l}\text { New Zealand Dental } \\
\text { Association }\end{array}$ & $\begin{array}{l}\text { Practice Guideline: } \\
\text { Guidelines for Child } \\
\text { Protection }\end{array}$ & & $\begin{array}{l}\text { April } 2001 \\
\text { (reviewed } \\
\text { September 2006) }\end{array}$ \\
\hline $\begin{array}{l}\text { New Zealand Nurses } \\
\text { Organisation }\end{array}$ & $\begin{array}{l}\text { Practice Position Statement: } \\
\text { Family Violence }\end{array}$ & & 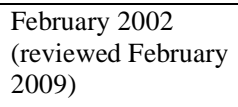 \\
\hline $\begin{array}{l}\text { Nursing Council of New } \\
\text { Zealand }\end{array}$ & Code of Conduct for Nurses & & November 2009 \\
\hline $\begin{array}{l}\text { New Zealand College of } \\
\text { Clinical Psychologists }\end{array}$ & $\begin{array}{l}\text { Code of Ethics for } \\
\text { Psychologists Working in } \\
\text { Aotearoa / New Zealand }\end{array}$ & & $\begin{array}{l}2002 \text { (updated } \\
\text { April 2004) }\end{array}$ \\
\hline \multicolumn{4}{|l|}{ Individual Hospitals } \\
\hline Starship Hospital (public) & $\begin{array}{l}\text { Starship Children's Health } \\
\text { Clinical Guideline "Abuse } \\
\text { and Neglect" }\end{array}$ & & May 2010 \\
\hline $\begin{array}{l}\text { Wakefield Health } \\
\text { Limited (Wakefield } \\
\text { Hospital) (private) }\end{array}$ & Policy: Abuse and Neglect & WHLC.01.08 & $\begin{array}{l}\text { November } 2006 \\
\text { (reviewed July } \\
\text { 2011) }\end{array}$ \\
\hline $\begin{array}{l}\text { Southern Cross Hospitals } \\
\text { Limited (private) }\end{array}$ & $\begin{array}{l}\text { Prevention of Patient Abuse, } \\
\text { Neglect or Maltreatment }\end{array}$ & Doc $3.3 \mathrm{~KB} 4236$ & $\begin{array}{l}\text { December 2005 } \\
\text { (reviewed February } \\
\text { 2012) }\end{array}$ \\
\hline
\end{tabular}


XII APPENDIX FIVE: PROFESSIONAL ASSOCIATIONS

CONTACTED THAT DID NOT HAVE UNIQUE CHILD ABUSE PROTOCOLS

\begin{tabular}{|l|l|l|}
\hline \multicolumn{1}{|c|}{ Professional body } & Absence of protocol confirmed by & \multicolumn{1}{|c|}{ Comment } \\
\hline $\begin{array}{l}\text { Paediatric Society of New } \\
\text { Zealand }\end{array}$ & $\begin{array}{l}\text { Dr Patrick Kelly (personal email } \\
\text { correspondence dated 13 February } \\
2012) .\end{array}$ & $\begin{array}{l}\text { Members would be subject to } \\
\text { employer protocols (eg, DHB or } \\
\text { public / private hospital). }\end{array}$ \\
\hline $\begin{array}{l}\text { Royal Australian and New } \\
\text { Pealand College of }\end{array}$ & $\begin{array}{l}\text { Katherine Minnett (personal email } \\
\text { correspondence dated 24 January } \\
\text { 2012). }\end{array}$ & $\begin{array}{l}\text { Members would be subject to } \\
\text { employer protocols (if any). }\end{array}$ \\
\hline $\begin{array}{l}\text { Royal New Zealand College } \\
\text { of General Practitioners }\end{array}$ & $\begin{array}{l}\text { Francis Townsend (telephone } \\
\text { conversation on 28 June 2012). }\end{array}$ & $\begin{array}{l}\text { Members would be subject to } \\
\text { employer protocols (DHB or PHO). }\end{array}$ \\
\hline
\end{tabular}




\section{APPENDIX SIX: CHART OF CHILD ABUSE INTERVENTION PROTOCOLS IN THE NEW ZEALAND}

\section{HEALTH SECTOR}

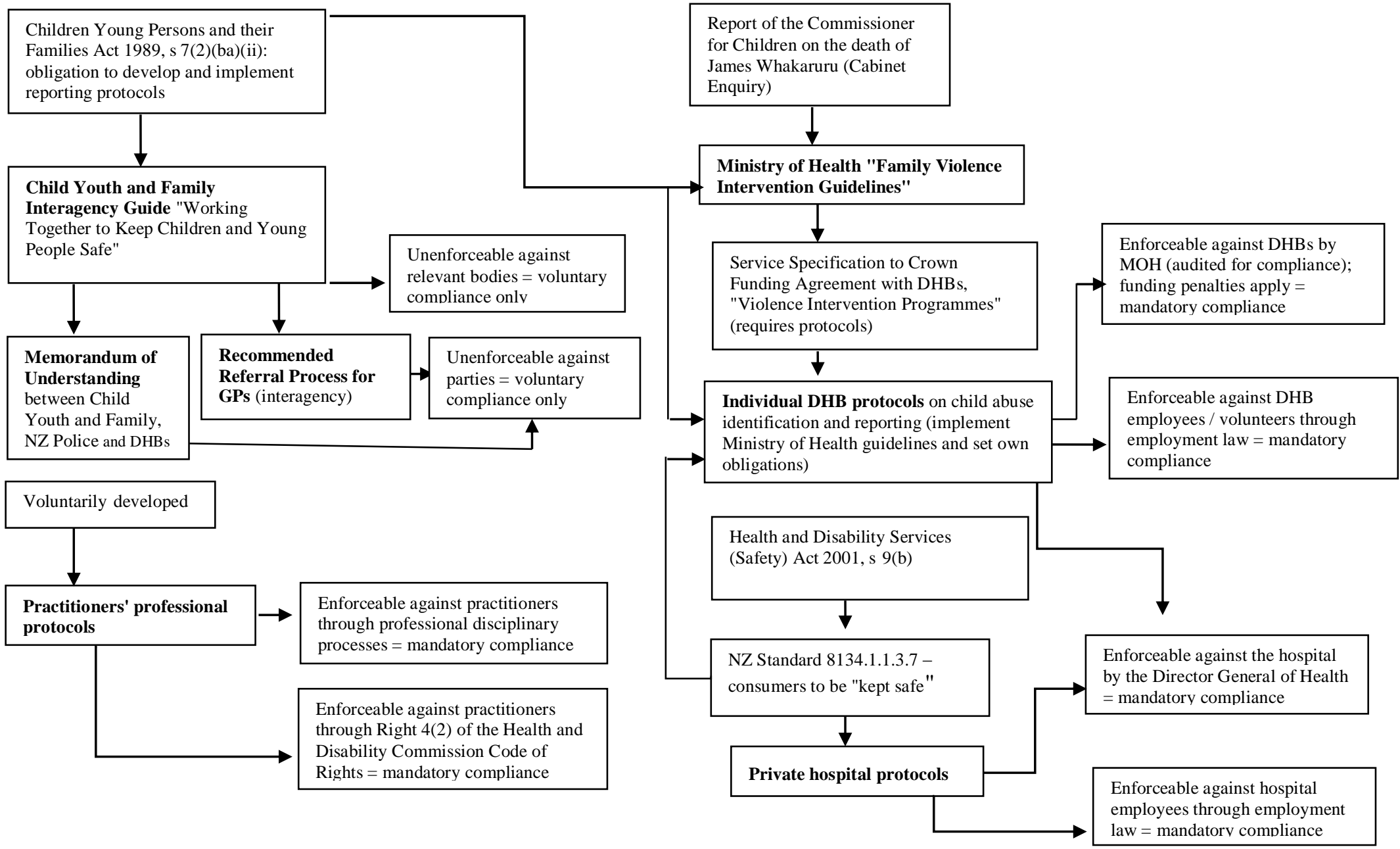


(2013) 44 VUWLR 